\title{
The Finnish matriculation examination in biology from 1921 to 1969 - trends in knowledge content and educational form
}

\author{
Jakke Neiro ${ }^{1}$ and Niko Johansson ${ }^{2}$ \\ ${ }^{1}$ Department of Zoology, University of Oxford, United Kingdom \\ ${ }^{2}$ Finnish Museum of Natural History, University of Helsinki, Finland
}

The history and evolution of science assessment remains poorly known, especially in the context of the exam question contents. Here we analyze the Finnish matriculation examination in biology from the 1920s to 1960s to understand how the exam has evolved in both its knowledge content and educational form. Each question was classified according to its topic in biology, and its cognitive level by Bloom's taxonomy. Overall, the exam progressed from a rather dichotomous test of botany and zoology to a modern exam covering biology from biochemistry to environmental science, reflecting the development of biology as a scientific discipline. The contribution of genetics increased steadily, while ecology witnessed a decline and a renaissance during the same time period. The biological profile of the questions was established by the 1950s. The educational standard and cognitive demand of the questions was always high and established by the 1940s.

Keywords: Finnish matriculation examination, biology education, Bloom's taxonomy, history of science education, assessment content analysis

\section{Tiivistelmä}

Luonnontieteellisten koekysymysten historiaa ja kehitystä on tutkittu hyvin vähän. Biologian ylioppilaskokeen kysymyksiä tarkasteltiin 1920-luvulta 1960-luvulle koekysymysten sisällöllisen ja opetuksellisen kehityksen selvittämiseksi. Kysymykset luokiteltiin biologisiin sisältöluokkiin, kun taas kognitiivinen taso arvioitiin Bloomin asteikolla. Tarkastelujakson aikana koe kehittyi kaksijakoisesta kasvi- ja eläintiedettä käsittelevästä kuulustelusta uudenaikaiseksi kokeeksi, joka tarkasteli biologiaa biokemiasta ympäristötieteeseen, heijastaen biologian kehitystä tieteenalana. Perinnöllisyystieteen osuus kokeessa kasvoi tasaisesti, kun taas ekologia koki jonkinasteisen taantuman ja uudelleentulemisen samalla aikavälillä. Kysymysten biologinen profiili vakiintui 1950-luvulla. Kysymysten opetuksellinen taso ja kognitiivinen vaatimustaso oli korkea alusta saakka ja vakiintui jo 1940luvulla.

Avainsanat: ylioppilaskoe, biologian opetus, Bloomin taksonomia, luonnontieteellisen opetuksen historia, arvioinnin sisältöanalyysi
Article Details

LUMAT General Issue Vol 8 No 1 (2020), 162-199

Received 12 June 2019 Accepted 13 March 2020 Published 22 June 2020

Pages: 38

References: 77

Correspondence: jakke.neiro@helsinki.fi

https://doi.org/10.31129/ LUMAT.8.1.1376 


\section{Introduction}

Current educational research focuses on contemporary issues, and the historical development of education is often overlooked (Eymard-Simonian, 2000; SáezRosenkranz, 2016). However, as in all social sciences and humanities, a historical viewpoint can complement educational research with a systematic synthesis of ideas, facts, and past events to answer problems, identify future trends and delineate different interactions and causalities (Cohen et al., 2013; Gall et al., 1996; SáezRosenkranz, 2016). The research in the history of education has concentrated on the history of educators as well as educational institutions and general practices, and only a few studies have looked into the history of educational content and assessment, let alone in biology (Caroli, 2019; Jenkins, 1979; Rosenthal, 1990; Sáez-Rosenkranz, 2016; Virta, 2014). In order to study the history of biology assessment successfully, expertise from three distinct fields, biology, education, and history, must be integrated in an interdisciplinary way. In this article, we examine the history of formal assessment in biology in view of both knowledge content and educational form by analyzing the biology questions of the Finnish matriculation examination over a timespan of five decades from 1921 to 1969.

\subsection{The Finnish matriculation examination}

The Finnish matriculation examination (FME) is the final exam of the upper secondary school that was instated in 1852 (Virta, 2014). Initially, the exam sessions were held at the University of Helsinki (known as the Imperial Alexander University before 1919), but from 1874 onwards directly in schools (Virta, 2014). According to Kaarninen and Kaarninen (2002), only four compulsory subjects were tested before 1921: Finnish, Swedish, one elective foreign language (Latin, German, French or Russian) and mathematics. The authors note that the exam questions were prepared by an autonomous Matriculation Examination Committee (from 1921 named the Matriculation Examination Board, MEB), which consisted of academics from the University of Helsinki and senior teachers from upper secondary schools. Therefore, Kaarninen and Kaarninen (2002) emphasize that the exam has always been influenced by the latest advances in Finnish academia, which here is understood as higher or tertiary education, universities and research institutions in Finland. In 1921, the test battery in humanities and natural sciences (Fin. Reaalikoe, Swe. Realprovet) was introduced, including physics, chemistry, biology, geography, history, and 
religion. The test battery was unique to school systems within Western Europe, as the examinee could freely choose questions from different subjects in both humanities and sciences, which Kaarninen and Kaarninen (2002) see to reflect the Humboldtian ideal of the Finnish education system. The test batteries consisted of almost exclusively essay-based questions, in accordance with the written exams in Finnish and other languages. Towards the end of the century, this format was criticized for being obsolete and favoring languages over sciences, and the test battery was divided into independent subject-specific tests in 2005, including a separate exam in biology with a more diverse set of question formats. Moreover, the examinee could now choose whether to take the exams in the spring or autumn, whereas before this the autumn exam had been for resits only. In the 2010s, the examination has gradually been digitalized, and in 2018 the exam in biology was taken online for the first time (Tuulosniemi, 2019). Over the years, the number of students matriculating each year has risen from about 1000 in the 1920 s to 30 ooo today (Tuulosniemi, 2019).

Throughout its entire existence, the MEB and the exam have elicited respect and fear alike in both students and teachers (Vuorio-Lehti, 2007). The questions have always been criticized for being overly academic and demanding, unlinked to normal school teaching, although the exam has also been praised for these very same reasons (Kaarninen \& Kaarninen, 2002). In addition, the exam has been claimed to direct the teaching and learning more than the formal curriculum, commonly known as the backwash effect in educational research (Ahvenisto et al., 2013; Virta, 2014). However, backwash is not necessarily negative, as it may clarify and strengthen the formal curriculum, but if the exam assesses some areas disproportionately, it can adversely skew the curriculum (Ahvenisto et al., 2013; Virta, 2014).

\subsection{The theory of educational assessment}

McTighe and Ferrara (1998) subdivide the assessment of learning into three types: diagnostic, formative and summative. Diagnostic assessment includes, e.g. pre-exams to clarify the starting level of students, formative assessment encompasses routine assignments, e.g. homework, self-evaluations and learning diaries, while summative assessment denotes the final comprehensive assessment, e.g. exams and theses. Historically, as a final essay-based exam of upper secondary school, the FME can be considered to represent a summative assessment of learning, and therefore the history of FME in biology can specifically be seen as the history of summative assessment in science education. The theoretical framework of assessment by 
McTighe and Ferrara (1998) has been the most popular in characterizing FME in corresponding contemporary studies (Lindholm, 2017; Rostila, 2014; Tikkanen, 2010).

Bloom's taxonomy or hierarchy is widely used to quantify the success and standard of teaching and learning, and it has become the main approach to study the questions of the FME (Bloom, 1956; Lindholm, 2017; Rostila, 2014; Tikkanen, 2010; Vitikainen, 2014). The taxonomy encompasses six cognitive levels: knowledge, comprehension, application, analysis, synthesis and evaluation (Bloom, 1956). The taxonomy is also called a hierarchy, as the levels are ranked in the order of increasing cognitive difficulty, complexity and abstractness (Bloom, 1956).

Table 1. The revised Bloom's taxonomy (Krathwohl \& Anderson, 2009). Short biological example tasks are given for each category.

\begin{tabular}{|c|c|c|c|c|c|c|}
\hline & Know & Comprehend & Apply & Analyze & Evaluate & Create \\
\hline Facts & $\begin{array}{l}\text { List cell } \\
\text { organelles }\end{array}$ & $\begin{array}{l}\text { Interpret } \\
\text { organelle image }\end{array}$ & $\begin{array}{l}\text { Use math } \\
\text { formula }\end{array}$ & $\begin{array}{l}\text { Categorize } \\
\text { organelles }\end{array}$ & $\begin{array}{l}\text { Evaluate } \\
\text { article }\end{array}$ & $\begin{array}{l}\text { Create a } \\
\text { diagram of a cell }\end{array}$ \\
\hline Concepts & $\begin{array}{l}\text { List organelle } \\
\text { functions }\end{array}$ & $\begin{array}{l}\text { Explain } \\
\text { evolution }\end{array}$ & $\begin{array}{l}\text { Interpret } \\
\text { crossing }\end{array}$ & $\begin{array}{l}\text { Fossils as } \\
\text { evidence for } \\
\text { evolution }\end{array}$ & $\begin{array}{l}\text { Evaluate } \\
\text { Darwinism }\end{array}$ & $\begin{array}{l}\text { Create new } \\
\text { phylogeny }\end{array}$ \\
\hline Methods & $\begin{array}{l}\text { List steps in the } \\
\text { experiment }\end{array}$ & $\begin{array}{l}\text { Explain steps in } \\
\text { experiment }\end{array}$ & $\begin{array}{l}\text { Use a } \\
\text { method to } \\
\text { solve a task }\end{array}$ & $\begin{array}{l}\text { Compare two } \\
\text { methods }\end{array}$ & $\begin{array}{l}\text { Evaluate } \\
\text { method }\end{array}$ & $\begin{array}{l}\text { Create new } \\
\text { method }\end{array}$ \\
\hline Metacognition & $\begin{array}{l}\text { List learning } \\
\text { styles }\end{array}$ & $\begin{array}{l}\text { Describe } \\
\text { learning styles }\end{array}$ & $\begin{array}{l}\text { Develop } \\
\text { study skills }\end{array}$ & $\begin{array}{l}\text { Compare } \\
\text { learning styles }\end{array}$ & $\begin{array}{l}\text { Evaluate } \\
\text { learning style }\end{array}$ & $\begin{array}{l}\text { Create new } \\
\text { learning style }\end{array}$ \\
\hline
\end{tabular}

Bloom's original taxonomy analyzes only the level of cognition, but not the level of facts to be processed, and therefore Krathwohl and Anderson (2009) have complemented the taxonomy by adding a second dimension, the knowledge dimension including facts, concepts, methods and metacognition, and by modifying the cognitive process dimension so that creation (synthesis in Bloom's original taxonomy) is ranked over evaluation (Table 1). Facts and concepts overlap to some extent, but facts include single details and terminology ("Name the organelles of the cell"), while concepts encompass more general understanding ("What is the function of cell organelles?”). Methods include the knowledge of research methodology of an academic discipline ("How have the cell organelles been discovered?"), while metacognition denotes the students' knowledge of the relevance of the knowledge for themselves (Krathwohl \& Anderson, 2009). Furthermore, metacognition encompasses the students' awareness of their learning styles and techniques with regard to a given study topic (Krathwohl \& Anderson, 2009). 


\subsection{The education of biology}

In the $20^{\text {th }}$ century, biology as a scientific discipline underwent a drastic change from natural history to modern life science (Mayr, 1982). Therefore, the content of the biological curriculum has been gradually revised, mostly due to the advances in genetics, and even today it is being discussed which biological novelties should be included in the revised curriculum (Goldenfeld \& Woese, 2007; Kinchin, 2010). Here, we define a biological novelty as a general term encompassing biological discoveries, concepts, and theories. We follow Mayr (1997) and regard a discovery as a single item of novel experimental knowledge of a biological phenomenon and a concept as an item of theoretical knowledge explaining a given discovery and linking it to biological theory. Lastly, a theory is seen as an explanation of a biological phenomenon that integrates a multitude of biological concepts. It is widely assumed that science and especially biology develops faster than ever before, but whether the time of introducing biological novelties into exams has changed over the years has never been properly clarified (Kurzweil, 2014; National Research Council, 2009). In recent years,

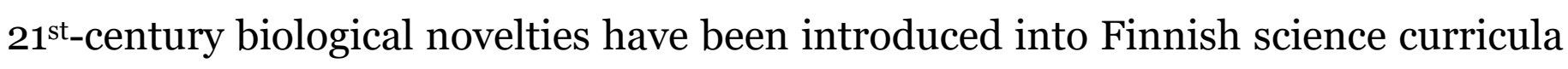
and exams rather quickly, e.g. CRISPR-Cas9 and induced pluripotent stem cells (iPSC) (Happonen et al., 2016).

The field of biology can be divided into subdisciplines in different ways, e.g. by stressing the studied organism group such as zoology or microbiology, the biological phenomenon such as genetics or physiology, or stressing applied research such as clinical microbiology or conservation biology. A couple of general classification schemes have been devised, but in educational research of the biology exam in the FME the framework of the National Research Council (2012) has emerged as the most popular (Lindholm, 2017; Rostila, 2014). As a simple and general classification, it is well suited for categorizing and comparing biological questions from different historical periods. The classification system subdivides biology into four broad categories:

1. LS1 From molecules to organisms

2. LS2 Ecosystems: interactions, energy, and dynamics

3. LS3 Heredity: inheritance and variation of traits

4. LS4 Biological evolution: unity and diversity 


\section{Aims and study questions}

Was old school a good school? In this article, we inspect the FME in biology to understand how the exam changed in both biological knowledge content and educational form from 1921 to 1969. Previously, the modern FME in biology (20092015) and its educational characteristics have been analyzed by Rostila (2014) and Lindholm (2017), who applied Bloom's taxonomy and McTighe's and Ferrara's assessment model to the exam questions. The exam in chemistry has been analyzed by Tikkanen (2010) and Vilhunen and Hopia (2012), in religion by Vitikainen (2014), and in history and social studies by Ahvenisto et al. (2013) and Virta (2014). Only Virta (2014) analyzed the exam from a historical perspective, and therefore this study aims to shed light on the development of a science exam in the FME for the first time. The study questions are as follows:

\section{Knowledge content:}

-What trends can be found in the biological knowledge content of the FME from 1921 to 1969 ?

-At what timeframe were biological novelties introduced to the exam?

\section{Educational form:}

-What types of questions were asked?

-What trends can be seen with respect to Bloom's revised taxonomy?

-Were questions in different biological categories (National Research Council)

equal with respect to Bloom's revised taxonomy? In other words, is there an interaction with the question topic and its cognitive demand?

The answers to these questions will help us understand how the science curriculum in the Finnish upper secondary school has evolved alongside both national and international trends, which in turn helps us predict the future of biological teaching. Furthermore, this study helps us identify questions of high educational standard, which may be used as an inspiration for devising future exams. Finally, this study is important for seeing whether certain biological subdisciplines have exhibited a certain educational profile compared with other subdisciplines, which will help us identify the special educational character of biology as a whole. 


\section{Materials and methods}

\subsection{The exam material}

The exams both in Finnish and Swedish from 1921 to 1969 were obtained from the free-access Digital Archives of the National Archives of Finland as scanned images from the online repository (http://digi.narc.fi/ylioppilastehtavat.html). Almost all exams had been preserved, only the exams from autumn 1921 to autumn 1923 were missing. From the test battery in sciences and humanities, only the biological questions from the section of biology and geography were chosen for further analysis. In the first years of the FME, biology and geography were taught as a single subject making it challenging in some instances to distinguish the biological questions from the geographical. Therefore, all geographical questions with some biotic component were considered to also be biological in character ("the nature of Iceland"), but questions with a clear abiotic component were left out (see Supplementary Material for chosen questions). It is possible that some questions from the section of physics and chemistry or psychology had a biological component, but these were not included in this study, as the number of these interdisciplinary questions is known to be minute during the studied time period (Kaarninen \& Kaarninen, 2002). Furthermore, the exam questions in Finnish and Swedish as a first language have included essay-type questions on biological and other scientific themes. However, these questions were not included in this study, as the primary purpose of this assessment is to evaluate the student's literal and language skills rather than scientific knowledge (Kaarninen \& Kaarninen, 2002).

\subsection{Trends in knowledge content}

Content analysis combining both qualitative and quantitative aspects was applied to all exam questions. Content analysis is a common approach in educational and social sciences to reduce and synthesize disorganized documents and identify the most important characteristics of the material (Neuendorf, 2016). Furthermore, content analysis can be used to historical documents, and for example, the history of the Finnish chemistry curriculum has been studied with this method previously (Vaskuri, 2017). The exam questions are thankful in the respect that they constitute a limited source of historical material, and therefore the drawback of overlooking important documents does not exist (Faire, 2016). Only some questions from the early 1920 s were missing, but there is no reason to believe that the questions would have been 
radically different from the other questions of the decade.

Content analysis was applied in two regimes, here termed qualitative and quantitative. For qualitative content analysis, the biological knowledge content of each question was interpreted, analyzed and characterized as a representation of a biological subdiscipline. For example, several questions of the form "the plant family $x$ " in the 1920 s were synthesized to reflect an emphasis on plant systematics and taxonomy. In our qualitative content analysis, the questions were encoded into open categories of biological knowledge content that were considered to best characterize a given question.

For quantitative content analysis, the exam questions were strictly classified into one of four biological categories according to the National Research Council (2012). If the question had an integrative character, the main category was chosen (see Supplementary Material for classification and detailed criteria). For example, the structure of chromosomes was considered to belong to Genetics and not Molecules to organisms, while the drought tolerance of plants was seen as Ecology and not Molecules to organisms. The questions were classified independently by each author (Rater A and Rater B), and the interrater reliability was evaluated with crosstabulation and kappa analysis (Hallgren, 2012; McHugh, 2012). Kappa analysis is a common statistical technique used to evaluate whether two or more independent researchers agree on a given classification. The frequencies of each category were calculated for each decade, and the interdecadal (ID) change in question frequencies was compared with the chi-squared test of independence using Yates' correction and Fisher's exact test. Fisher's exact test was used when the sample size was not large enough for the chi-squared test of independence, and Yates' correction was used to prevent overestimation of statistical significance for small data samples (Ross, 2017). Both the chi-squared test of independence and Fisher's exact test are standard statistical tests used to compare frequencies of two or more categories (Ross, 2017).

To quantify the rate of introduction of biological novelties, all questions testing novelties were selected. For each biological novelty, the approximate year of academic establishment (AE) of the novelty was estimated from the history of science literature. Here, AE is understood as the approximate year when the biological novelty was broadly and internationally acknowledged. First, the primary scientific reference of the biological novelty was identified, after which succeeding literature was analyzed. For discoveries, AE is the year when the discovery had been conceptualized and linked to biological theory, while for concepts AE is the year when the concept had been 
linked to biological theory. Lastly, for biological theories, AE is the year when the theory had been acknowledged in preference of other alternatives. The explanation for how AE was estimated is presented in the Supplementary Material for each biological novelty. The authors estimated AE independently, and the mean of these estimates was used to reduce interrater variability. The time of introduction $(\mathrm{T})$ was calculated as the difference between the year of appearance in the FME and AE (Equation 1).

$$
\mathrm{T}=\mathrm{FME}-\mathrm{AE}
$$

(Equation 1)

In order to see whether there was a temporal change in the rate of introduction, linear regression analysis was performed by having the year of appearance as the independent variable and the time of introduction $(\mathrm{T})$ as the dependent variable (see Supplementary Material for details). Linear regression is commonly used to fit a linear model to continuous data and to assess whether the trend has been increasing or decreasing (Ross, 2017). All the statistical tests were performed in the R environment (v. 3.6.o) (R Core Team, 2019).

\subsection{Trends in educational form}

As for knowledge content, both qualitative and quantitative content analysis was performed on the exam questions in order to capture their educational form. For qualitative content analysis, the questions were classified into open categories of educational form and the types of assessment, according to McTighe and Ferrara (1998). For quantitative analysis, the questions were classified into the revised Bloom's taxonomy cognitive categories by Krathwohl and Anderson (2009). The questions were classified independently by each author (Rater A and Rater B), and the interrater reliability was evaluated with cross-tabulation and kappa analysis (Hallgren, 2012; McHugh, 2012).

To test temporal changes quantitatively, the frequencies of each question type were calculated for each decade, and the ID change was tested with Fisher's exact test. Furthermore, the frequencies of question types were calculated for each biological category, and the category-wise frequencies were compared with Fisher's exact test (see Supplementary Material for details). 


\section{Results}

\subsection{General qualitative patterns of educational form from 1920 s to 1960s}

During the studied time period, almost all questions were essays, i.e. performancebased assessment of the product format according to McTighe and Ferrara (1998), and only a few crossing experiments were presented as solvable problems from the 1940 s onwards. A lot of the essay-type assignments were simply listed as headings and not directly as questions such as "The circulatory system of fish" or "The plant family Orchidaceae". If the essays were written as bona fide questions, the language was rather consistent and only the verbs selittää 'explain', tietää/veta 'know', kertoa/berätta om, redogöra 'tell', and tehdä selkoa/redogöra 'clarify' were used. No figures or illustrations were included in the exam, and therefore all the decade-specific figures (Figures 1-5) have been collected from contemporary schoolbooks to present how the exam topics were visualized in the study material.

\subsection{The 1920s - Plant systematics and comparative zoology}

From the 1920s, 46 questions in total had been preserved. During the 1920s, the questions in biology and geography comprised five to six questions, of which usually three to four were devoted to biology and the rest to geography. The focus on botany and zoology was clearly visible, as about $80 \%$ (35/46) dealt with these topics, while the remainder examined more general biological areas, including genetics, biogeography, evolutionary theory, microbiology, and anthropology (Figure 1).

In botany, a typical question of the decade inspected plant systematics, and altogether 12 taxa were tested (Table 2). Thus, the systematical questions constituted about half of all the botanical questions. Meanwhile, the other questions examined plant physiology, morphology, development, and also, some ecological aspects were included (Table 2).

In zoology, the emphasis was on different aspects of morphology, physiology and embryology (Table 3). A noteworthy proportion of these questions were from a comparative viewpoint, integrating evolutionary thought to the exam, and only a few were testing comprehension of particularly human physiology. The other questions inspected animal behavior, community ecology, and systematics (Table 3). 


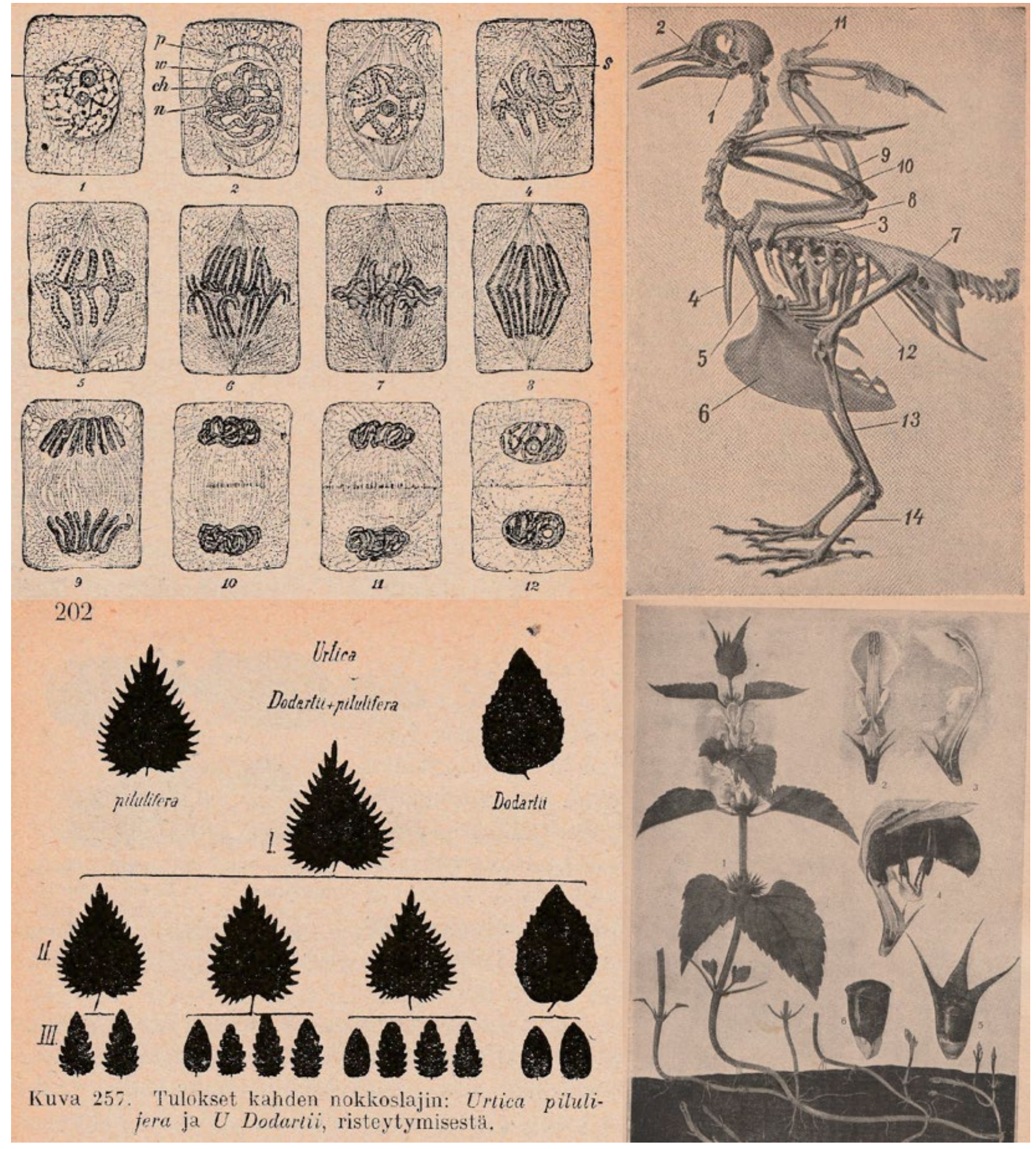

Figure 1. Visual overview of the exam question themes in the 1920s as illustrated in contemporary schoolbooks. (Top left) The structure and reproduction of plant cells. (Top right) Functional morphology of birds. (Bottom left) Mendelism. (Bottom right) The mint family (Lamiaceae). (Kivirikko, 1923). 
Table 2. Questions in plant systematics, morphology, physiology and development in the 1920s.

\begin{tabular}{|c|c|c|c|}
\hline Plant systematics: families & $\begin{array}{l}\text { Plant systematics: } \\
\text { higher taxa }\end{array}$ & $\begin{array}{l}\text { Plant morphology, } \\
\text { physiology and development }\end{array}$ & Plant ecology \\
\hline $\begin{array}{l}\text { Umbelliferae (the carrot family) } \\
\text { Lamiaceae (the mint family) } \\
\text { Scrophulariaceae (the figwort family) } \\
\text { Liliaceae (the lily family) } \\
\text { Orchidaceae (the orchid family) } \\
\text { Poaceae (the grasses) } \\
\text { Arecaceae (the palms) } \\
\text { Brassicaceae (the cabbage family) }\end{array}$ & $\begin{array}{l}\text { Cryptograms } \\
\text { Phanerogams (seed } \\
\text { plants) } \\
\text { Lichens } \\
\text { Algae }\end{array}$ & $\begin{array}{l}\text { Respiration } \\
\text { Adaptation to arid and moist } \\
\text { environments } \\
\text { Rhizomes } \\
\text { The life cycle of ferns } \\
\text { Structure of plant cells and their } \\
\text { reproduction }\end{array}$ & $\begin{array}{l}\text { Dispersal of } \\
\text { seed plants }\end{array}$ \\
\hline
\end{tabular}

Table 3. Animal and human morphology, physiology and development in the 1920s.

\begin{tabular}{|c|c|c|c|}
\hline Animal morphology & $\begin{array}{l}\text { Animal physiology } \\
\text { and development }\end{array}$ & $\begin{array}{l}\text { Human anatomy and } \\
\text { physiology }\end{array}$ & $\begin{array}{l}\text { Animal ecology, behavior } \\
\text { and systematics }\end{array}$ \\
\hline $\begin{array}{l}\text { Morphological adaption } \\
\text { of birds for flight } \\
\text { Functional morphology of } \\
\text { insect mouthparts } \\
\text { Mammalian tooth } \\
\text { morphology } \\
\text { Morphology of the cross } \\
\text { spider } \\
\text { Functional morphology of } \\
\text { bird legs }\end{array}$ & $\begin{array}{l}\text { The cardiovascular } \\
\text { system of fish } \\
\text { Development of frogs } \\
\text { The digestive system } \\
\text { of ruminants }\end{array}$ & $\begin{array}{l}\text { Digestive system } \\
\text { Eye } \\
\text { Blood } \\
\text { Nervous system }\end{array}$ & $\begin{array}{l}\text { Migration in fish } \\
\text { Brood behavior of passerine } \\
\text { birds } \\
\text { Parasitism } \\
\text { Protective mechanisms of } \\
\text { prey against predators } \\
\text { Salmonid fish }\end{array}$ \\
\hline
\end{tabular}

Regarding other subdisciplines of biology, there were a few questions on microbiology, but only one question was stated on genetics, namely an essay on Mendelism and its relevance for biology (Table 4). In ecology, the tasks focused on biogeographical and faunistic and floristic aspects (Table 4). The final question of the decade was the ominous "What do you know about negroes?", reflecting the attitudes toward human races of the time (Table 4).

Table 4. Microbiology, genetics, evolution and ecology in the 1920s.

\begin{tabular}{llll}
\hline Microbiology & Genetics & Evolution & Ecology \\
\hline Bacteria & Mendelism & Negroes and human races & Biogeography of Africa \\
Protozoa & & Biogeography of Australia \\
& & Biogeography of Iceland \\
& & Tundra biome \\
\hline
\end{tabular}

A lot of the questions tested only factual knowledge, e.g. "The plant family Orchidaceae," but many questions were already asking for comprehension of biological concepts "What do you know about the structure of seeds and germination?" or "The structure and function of the human eye." Interestingly, some 
of the questions were cognitively rather advanced and involved elements of analysis, for example, the examinees were presented the following questions: "How do phanerogams and cryptogams compare to each other," "The structure of the mouthparts of insects and their adaptions," and "The structure and morphology of mammalian teeth in relation to diet.”

\subsection{The 1930s - Genesis of genetics and diverse Darwinism}

From the 1930s, 83 questions were asked on various aspects of biology. The emphasis on botany and zoology continued from the previous decade, but more questions were asked on both genetics and evolutionary theory. The botanical and zoological questions were asked from more diverse perspectives compared to the previous decade (Figure 2).

As for the botanical questions, plant systematics had a lesser role than previously, and instead there was a stronger emphasis on plant morphology, physiology and development (Table 5). Moreover, there was also one applied question on the cultivation of coffee, tea and cocoa (Table 5). 


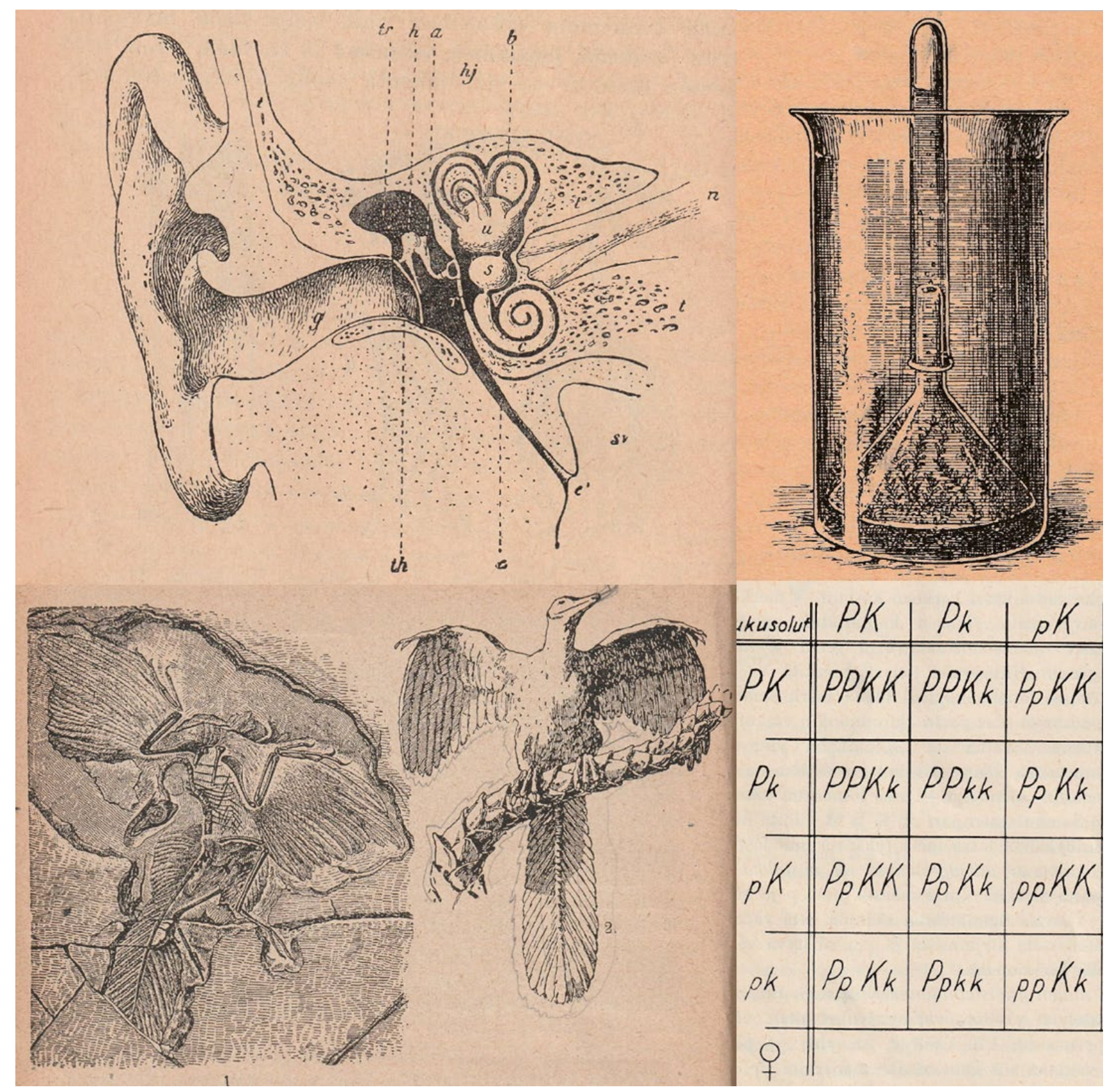

Figure 2. Visual overview of some of the questions in the 1930s as examined in contemporary schoolbooks. (Top left) The structure and function of the human ear. (Top right) Respiration in plants. (Bottom left) The evidence for the theory of evolution. (Bottom right) Mendelism and Punnet squares. (G. Marklund \& Jalas, 1933). 
Table 5. Plant systematics, morphology, physiology and development in the 1930s.

\begin{tabular}{|c|c|c|c|}
\hline Plant systematics & Plant morphology & $\begin{array}{l}\text { Plant physiology and } \\
\text { development }\end{array}$ & Plants and agriculture \\
\hline $\begin{array}{l}\text { Pine (Pinus sylvestris) } \\
\text { Spruce (Picea abies) } \\
\text { Poaceae (the grasses) } \\
\text { Diatoms } \\
\text { Cacti } \\
\text { Potatoes } \\
\text { Gymnosperms and } \\
\text { angiosperms } \\
\text { Thalloid plants }\end{array}$ & $\begin{array}{l}\text { Leaf morphology } \\
\text { Morphology of } \\
\text { lichens and mosses } \\
\text { Plant trichomes } \\
\text { Morphology of fungi } \\
\text { Root morphology }\end{array}$ & $\begin{array}{l}\text { Water transport } \\
\text { Development of the fruit } \\
\text { Accessory fruits and flowers } \\
\text { Metabolism and respiration } \\
\text { Pollination } \\
\text { Nitrogen and plant nutrition } \\
\text { Secondary growth of trees }\end{array}$ & $\begin{array}{l}\text { Cultivation of coffee, tea } \\
\text { and cocoa }\end{array}$ \\
\hline
\end{tabular}

In zoology, there were more systematic questions than in the previous decade (Table 6). With respect to physiology, morphology and development, classical zoology still outnumbered human biology in terms of the number of exam questions (Table $6)$.

Table 6. Animal systematics, morphology, physiology and development along with human anatomy and physiology in the 1930s.

\begin{tabular}{|c|c|c|c|}
\hline $\begin{array}{l}\text { Animal } \\
\text { systematics }\end{array}$ & Animal morphology & $\begin{array}{l}\text { Animal physiology and } \\
\text { development }\end{array}$ & $\begin{array}{l}\text { Human anatomy and } \\
\text { physiology }\end{array}$ \\
\hline Ants & Rudimentary organs & Embryogenesis of the & Ear \\
\hline Finnish reptiles & Morphology of human & lancelet & Muscles \\
\hline Hawks and owls & parasites & Metamorphosis of insects & Tissue types \\
\hline $\begin{array}{l}\text { Finnish aquatic } \\
\text { mammals }\end{array}$ & $\begin{array}{l}\text { Functional morphology of } \\
\text { mammalian teeth }\end{array}$ & Respiration & Digestive system \\
\hline $\begin{array}{l}\text { Carnivores and } \\
\text { rodents }\end{array}$ & $\begin{array}{l}\text { Functional morphology of } \\
\text { gliding animals }\end{array}$ & & \\
\hline Cartilaginous and & Morphology of butterflies & & \\
\hline bony fish & $\begin{array}{l}\text { Keratin formations of } \\
\text { vertebrates } \\
\text { Morphology of the platypus }\end{array}$ & & \\
\hline
\end{tabular}

The decade saw a rise in the number of conceptual questions in ecology in contrast to the biogeographical questions that had been prevalent in the previous decade (Table 7). Also, some behavior-related questions were included (Table 7). In the previous decade, evolutionary issues had been integrated through systematics and comparative morphology, but in the 1930s, the examinees had to analyze the concepts of the evolutionary theory itself (Table 7). The genetics questions tested knowledge on Mendelism and sex determination (Table 7). In addition, the decade witnessed the rise of biochemical, cytological and microbiological questions (Table 7). Lastly, there was one question on human races at the beginning of the decade (Table 7 ). 
Table 7. Microbiology, genetics, evolution, ecology and behavior in the 1930s.

\begin{tabular}{|c|c|c|c|}
\hline $\begin{array}{l}\text { Biochemistry, cell biology } \\
\text { and microbiology }\end{array}$ & Genetics & Evolution & Ecology and behavior \\
\hline $\begin{array}{l}\text { Cell division } \\
\text { Cytoplasm } \\
\text { Cell nucleus } \\
\text { Yeast } \\
\text { Enzymes } \\
\text { Vitamins } \\
\text { Hormones } \\
\text { Temperature-dependency of } \\
\text { life }\end{array}$ & $\begin{array}{l}\text { Mendelism } \\
\text { Sex determination }\end{array}$ & $\begin{array}{l}\text { Artificial selection } \\
\text { Fossils } \\
\text { Homology and analogy } \\
\text { Human evolution } \\
\text { Mutations } \\
\text { Rudimentary organs } \\
\text { Biogeography and evolution } \\
\text { Acquired characteristics } \\
\text { Human races }\end{array}$ & $\begin{array}{l}\text { Symbiosis } \\
\text { Distribution of species } \\
\text { Camouflage and mimicry } \\
\text { Plankton } \\
\text { Boreal forests and rain } \\
\text { forests } \\
\text { Principles of the } \\
\text { ecological community } \\
\text { Eusociality of bees } \\
\text { Migration of fish } \\
\text { Animal herds }\end{array}$ \\
\hline
\end{tabular}

In the 1930s, there were still questions testing simply knowledge, but questions testing comprehension and analysis increased in number. For example, the examinees were expected to find answers to analytic questions such as "What is the biological basis of plant and animal breeding and what methods are used for this," "How does parasitism affect the structure of the animal," "Darwinism, natural selection and the modern perceptions of the importance of selection for the origin of species," "Compare homology and analogy," and "Explain Linné's and Darwin's perceptions on the origin of species." In addition, there was one question of an evaluative character: "Plants as the foundation of animal and human existence."

\subsection{The 1940s - Mendelism, nutrition and developmental biology}

In the 1940s, 83 biological questions were asked. During WWII, the MEB took advantage of any cease-fire and organized several extraordinary exam sessions near the frontline whenever possible. In this decade, crossings established themselves as standard questions in almost all exams, both plant and human physiology concentrated on nutrition, and the zoological questions had an emphasis on developmental biology (Figure 3). 


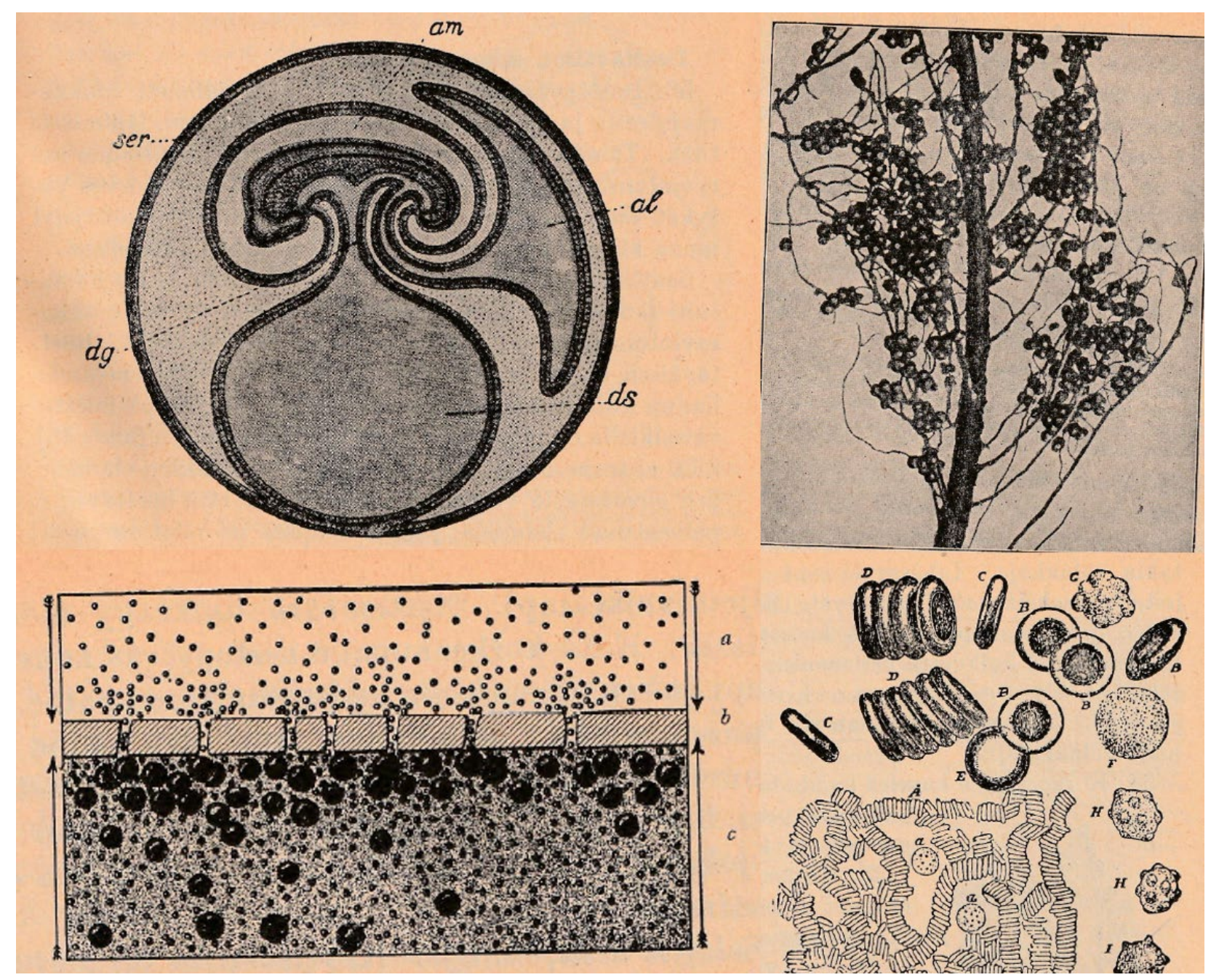

Figure 3. Visual overview of some of the question from the 1940s as illustrated in contemporary schoolbooks. (Top left) The structure of the mammalian embryo. (Top right) Nitrogen and the root nodules of legumes. (Bottom left) Osmosis and water transport in plants. (Bottom right) Blood cells. (G. Marklund \& Jalas, 1943).

In contrast to the two precedent decades, there were no systematic questions in botany, and the focus was firmly on plant morphology, physiology and development (Table 8). The decade can be best characterized by the focus on water transport, nitrogen sources and the nutrition of plants, as this theme was inspected several times from both a pure physical-chemical perspective (the mechanism of osmosis) and an applied perspective (the use of fertilizers). Lastly, there were some questions of an ecological character (Table 8). 
Table 8. Plant morphology, physiology, development and ecology in the 1940s.

\begin{tabular}{lll}
\hline Plant morphology & Plant physiology and development & Plant ecology \\
\hline Plant tissues & Alternation of generations & Overwintering in plants \\
Plant connective tissue & Photosynthesis and respiration & Parasitic plants \\
Cellulose & Fermentation & \\
Stem morphology & Fertilization in seed plants & \\
& Asexual reproduction & \\
& Nutrition and water transport & \\
\hline
\end{tabular}

Interestingly, all purely zoological questions inspected developmental biology (Table 9). In contrast to previous decades, the physiological questions were all on humans, or mammals and vertebrates in general (Table 9). Several of the physiological questions focused on nutrition and food processing, specifically in the human digestive system.

Table 9. Animal development and human anatomy, histology and physiology in the 1940s.

\begin{tabular}{lll}
\hline Animal development & Human anatomy and histology & Human physiology \\
\hline Nutrition of the embryo & Connective tissues & Digestion \\
Asexual reproduction & Heart & Hearing \\
Animal regeneration & Muscles & Connective tissues \\
Vertebrate morphogenesis & Cartilage and bone & Blood \\
Extraembryonic membranes & Pancreas & Thermoregulation \\
& Skin & Excretion \\
\hline
\end{tabular}

In this decade, the rise of genetics was even more prevalent, and the examinees were facing several questions on different aspects of genetics (Table 10). Also, evolutionary theory, cell biology and biochemistry were well represented (Table 10). Lastly, there were only a few questions on ecological themes (Table 10).

Table 10. Biochemistry, cell biology, microbiology, genetics, evolution and ecology in the 1940s.

\begin{tabular}{llll}
\hline $\begin{array}{l}\text { Biochemistry, cell biology } \\
\text { and microbiology }\end{array}$ & Genetics & Evolution & Ecology \\
\hline Protein & Genotype and phenotype & Darwinism & Carbon cycle \\
Vitamins & Crossing experiments & Lamarckism & Animal migration \\
Carbohydrates & Gene concept & Natural selection & \\
Multicellularity & Mendelism & Variation & \\
& Sex determination & Extinct organisms & \\
& Mutations & & \\
\hline
\end{tabular}

The general trend was still essays, but some of the crossing experiments were presented as solvable problems. There were few questions testing simply knowledge, but most required comprehension, application and analysis. For instance, the decade included several crossing experiments testing the application of Mendel's laws. The 
analytically most complex questions were likely "On extinct organisms that combine characters from different systematic groups and their relevance for our view on evolution," "How is it determined whether the egg cell develops into a boy or girl and how can the equal number of boys and girls be explained?," and "Compare respiration and fermentation in plants." Finally, there were a couple of questions where the examinees were asked to evaluate ideas and concepts: "How does modern research view Darwinian selection as the force of evolution?" and "Overview of the cell concept throughout history."

\subsection{The 1950s - Cytogenetics, human physiology and ecology}

In the 1950s, 79 biological questions were included in the FME. In this decade, the focus of genetics shifted increasingly from Mendelism to cytogenetics. In zoology, there were few questions on the physiology of animals since most were examining human physiology. Some renaissance of ecological and systematic questions could also be observed, having been more or less absent since the mid-1930s (Figure 4). 


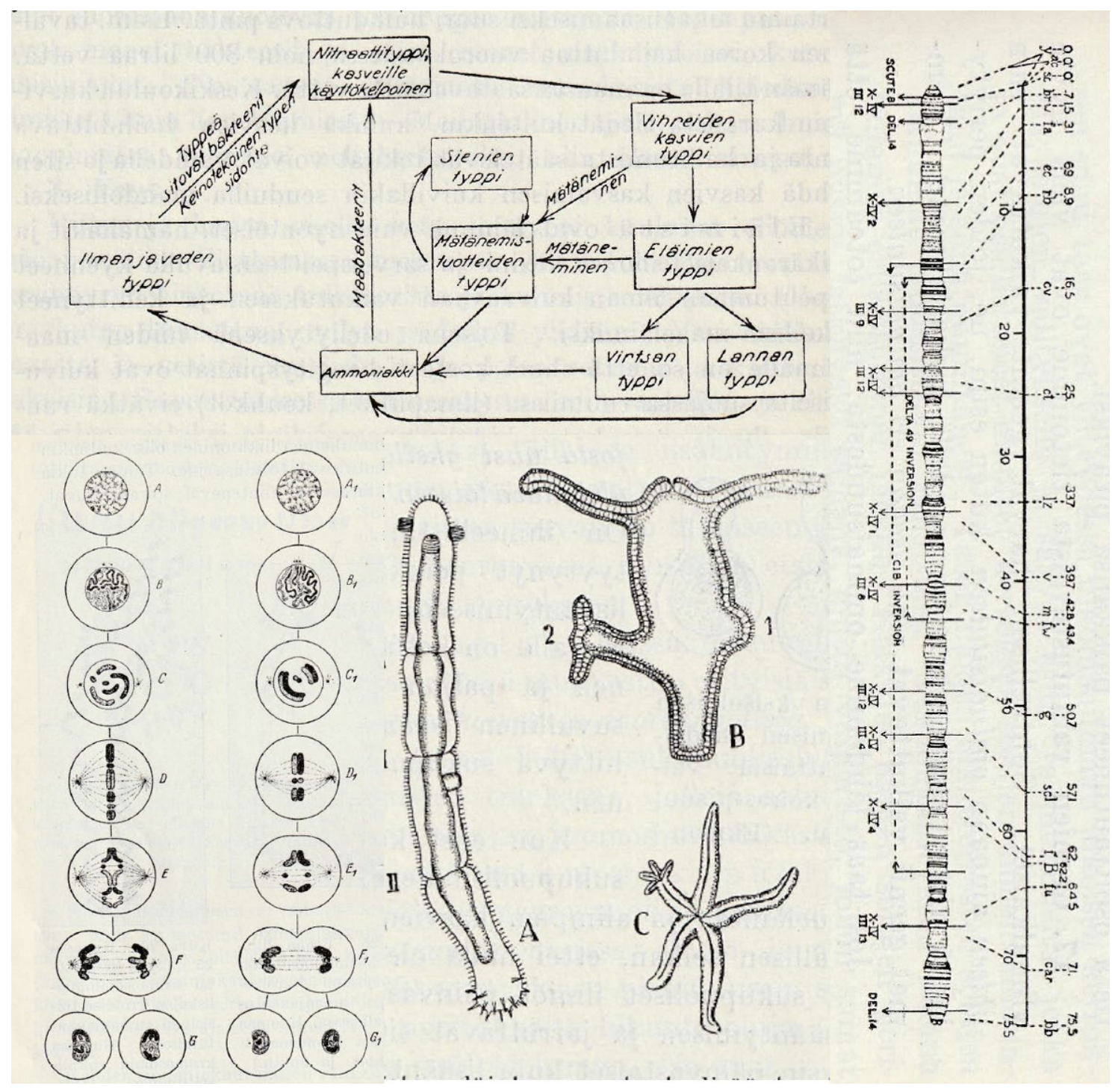

Figure 4. Visual overview of some of the questions from the 1950s as illustrated in contemporary schoolbooks. (Top left) The nitrogen cycle. (Right margin) Linkage and gene maps. (Bottom left) Chromosomes in mitosis and meiosis. (Bottom middle) Asexual reproduction and regeneration in animals. (Suomalainen \& Segerstråle, 1953).

In botany, most questions were inspecting plant physiology, although a few ecological questions were also included (Table 11). A new theme was phototropism, which had not been encountered in previous decades (Table 11). 
Table 11. Plant physiology, development and ecology in the 1950s

\begin{tabular}{ll}
\hline Plant physiology and development & Plant ecology \\
\hline Asexual and sexual reproduction & Overwintering of plants \\
Chlorophyll and photosynthesis & Aquatic vegetation \\
Water transport & \\
Nitrogen and nutrition & \\
Respiration & \\
Phototropism & \\
\hline
\end{tabular}

During the 1950s, a few systematic questions were asked for the first time since the 1930 s (Table 12). In addition, some assignments were on animal physiology and development, but otherwise, all the other assignments were on human physiology (Table 12).

Table 12. Animal systematics, development and physiology, and human anatomy and physiology in the $1950 \mathrm{~s}$

\begin{tabular}{lll}
\hline Animal systematics & $\begin{array}{l}\text { Animal physiology and } \\
\text { development }\end{array}$ & Human anatomy and physiology \\
\hline Winter birds & Asexual reproduction & Blood \\
Butterflies & Parthenogenetic reproduction & Endocrinology \\
& Functional morphology of aquatic & Digestion \\
& mammals & Nervous system \\
& Thermoregulation & Metabolisms of the fetus and mother \\
& & Muscles \\
\hline
\end{tabular}

In this decade, the focus of genetics turned increasingly from Mendelism and crossings to cytogenetics (Table 13). Interestingly, the examinees were asked for the first time to evaluate the negative effects of inbreeding and consanguineous marriages (Table 13). As for evolutionary theory, central evolutionary concepts were tested as in previous decades (Table 13). In addition, the decade witnessed a renaissance of ecology, as community ecology, biogeography and ecosystems were examined from different perspectives (Table 13). In terms of biochemistry, cell biology and microbiology, an overarching theme of the decade was energy and the physical and chemical limitations of life on earth (Table 13). 
Table 13. Biochemistry, cell biology, microbiology, genetics, evolution and ecology in the 1950s

\begin{tabular}{llll}
\hline $\begin{array}{l}\text { Biochemistry, cell biology } \\
\text { and microbiology }\end{array}$ & Genetics & Evolution & Ecology \\
\hline Bacterial cells & Mendelism & Human evolution & Plant communities \\
Eukaryotic cells & Crossing experiments & Biogeography and & Pest insects \\
Energy and metabolism & Chromosomes & evolution & Dispersal \\
Physical and chemical & Mutations & Homology and analogy & Peatlands \\
limitations of life & Linkage and crossing-over & Fossils & Submarine life \\
& Mutations & Selection & Grasslands and savannah \\
& Gene maps & Speciation & Nitrogen cycle \\
& Inbreeding & Producers and consumers \\
& Consanguineous marriage & & \\
\hline
\end{tabular}

Educationally, the exam did not change from the 1940s, and most questions were essays, although some crossing problems were presented as well. As in the 1940s, only a few questions were testing solely knowledge, as most assignments involved comprehension, application and analysis. The cognitively most challenging questions involving analysis and evaluation were likely "What does genetics say about consanguineous marriages?," "Compare natural and artificial classification systems," "How does evolution result in speciation?," "How do organisms differ from the nonliving nature?" and "Biogeography as evidence for the evolutionary theory." Furthermore, some questions included creative elements such as "Is human breeding possible in the view of genetics?"

\subsection{The 1960s - Towards modern biology and establishment}

In the 1960s, 92 biological questions were included in the FME. The decade is characterized by further modernization and the inclusion of novel genetic concepts, but otherwise, the biological and educational profile of the exam was similar to the trend established in the 1950 o (Figure 5). Here, we define modern biology as the integrative discipline of biology encompassing all the fields from biochemistry to ecology that formed during the latter half of the $20^{\text {th }}$ century. 

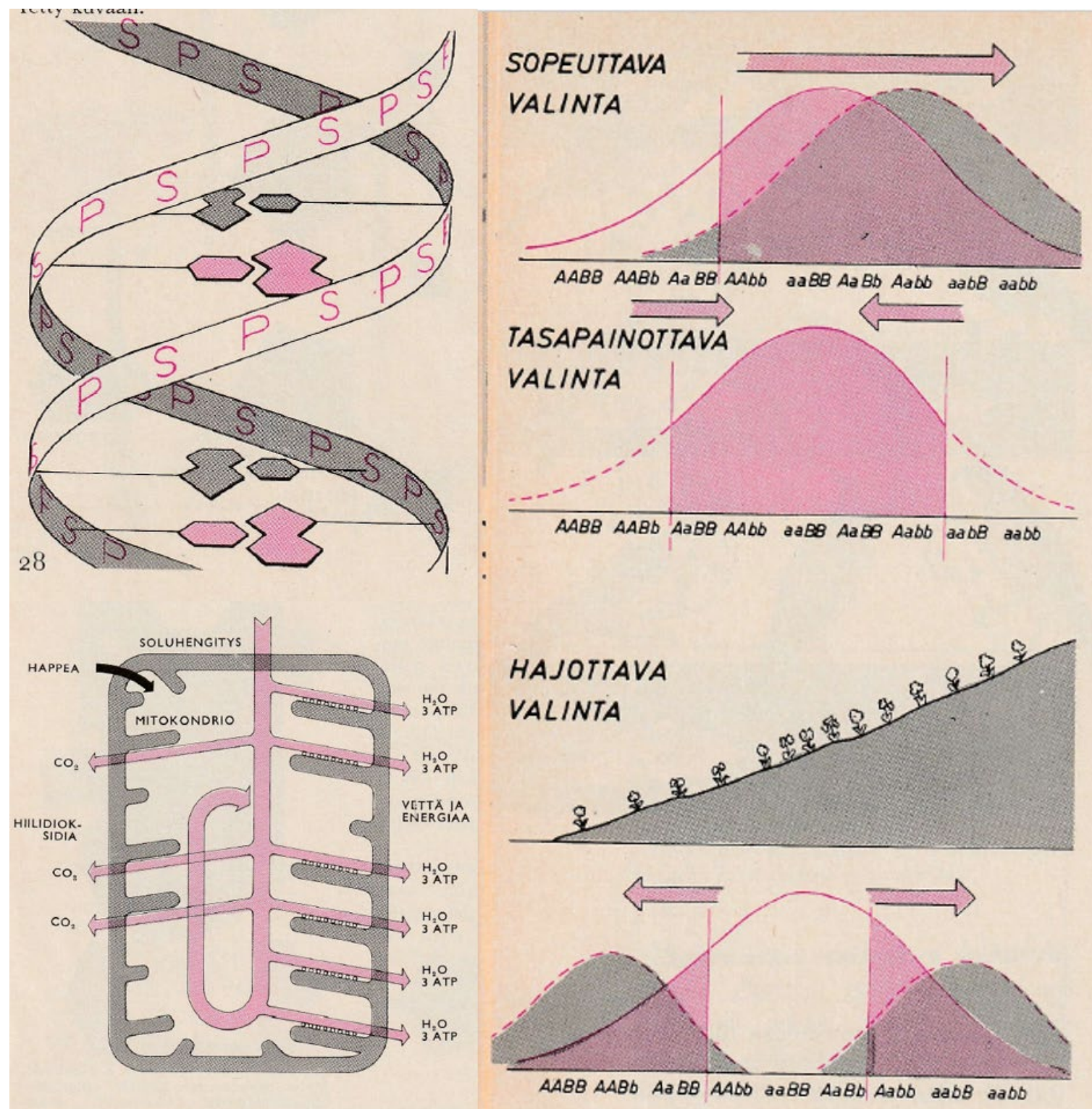

Figure 5. Visual overview of some of the questions of the 1960s. (Top left) The structure of chromosomes, including DNA. (Right margin) The mechanisms of selection. (Left bottom) Cellular metabolism. (Sorsa et al., 1966).

In the 1960s, the significance of botany and plants started to decline in the exam, but the exam nonetheless covered classical concepts of plant physiology (Table 14). Novel elements were plant hormones and the regulation of growth (Table 14). In addition, a few ecological questions were included (Table 14).

In the 1960s, there were only a couple of questions on classical zoology, and otherwise, the questions were testing human anatomy, histology and physiology (Table 15). In addition, there was the first purely clinical question when the examinees were asked to explain transplantations and tissue cultures (Table 15). 
Table 14. Plant physiology, development and ecology in the 1960s

\begin{tabular}{ll}
\hline Plant physiology and development & Plant ecology \\
\hline Water transport & Overwintering of plants \\
Nutrition and nitrogen & Finnish trees \\
Plant hormones & \\
Alternation of generations & \\
\hline
\end{tabular}

Table 15. Animal development and human anatomy, histology, physiology and medicine in the 1960s

\begin{tabular}{llll}
\hline $\begin{array}{l}\text { Animal } \\
\text { development }\end{array}$ & $\begin{array}{l}\text { Human anatomy } \\
\text { and histology }\end{array}$ & Human physiology & Medicine \\
\hline $\begin{array}{l}\text { Amphibian } \\
\text { development }\end{array}$ & $\begin{array}{l}\text { Germ layers } \\
\text { Neural tissue }\end{array}$ & $\begin{array}{l}\text { Digestion } \\
\text { Hormones and development }\end{array}$ & $\begin{array}{l}\text { Transplantation and tissue } \\
\text { culture }\end{array}$ \\
$\begin{array}{l}\text { Extraembryonic } \\
\text { membranes of birds }\end{array}$ & Blood & Tissue types & $\begin{array}{l}\text { Regeneration } \\
\text { Vitamins }\end{array}$ \\
$\begin{array}{l}\text { and mammals } \\
\text { Animal }\end{array}$ & Muscles & Mechanical senses & \\
regeneration & & Hearing & \\
\hline
\end{tabular}

In genetics, there were assignments on classical crossings, cytogenetics and other novel genetic concepts such as polyploidy (Table 16). Interestingly, there were a few questions on eugenics for the first time since the 1930s (Table 16). As for evolution, the questions examined the foundations and evidence for the evolutionary theory as well as the evolutionary history of life on earth (Table 16). Interestingly, there were relatively many questions about the Carboniferous period. In terms of ecology, the test asked for knowledge on ecosystems as well as ecological concepts (Table 16). With respect to cell biology and microbiology, the test asked classical questions on cellular structure, while the biochemical assignments focused on metabolism (Table 16).

Table 16. Biochemistry, cell biology, microbiology, genetics, evolution and ecology in the 1960s.

\begin{tabular}{llll}
\hline $\begin{array}{l}\text { Biochemistry, cell biology } \\
\text { and microbiology }\end{array}$ & Genetics & Evolution & Ecology \\
\hline Bacterial cells & Mendelism & Natural selection & Boreal forests \\
Eukaryotic cells & Crossing experiments & Lamarckism vs. & Peatlands \\
Energy and metabolism & Sex determination & Darwinism & Finnish lakes \\
& Chromosome structure & Rudimentary organs & Carbon cycle \\
& Meiosis & Fossils & Oxygen cycle \\
& Crossing over & Evolutionary benefit of & Nitrogen cycle \\
& Gene maps & sexual reproduction & Plankton \\
& Polyploidy & Human evolution & Producers and consumers \\
& Research methods in & Evolution of & \\
& genetics & photosynthesis & \\
& Eugenics & Mesozoic Era & \\
\hline
\end{tabular}


The educational profile of the exam was similar to the exam from the 1950s. Nonetheless, there were more tasks asking for the comprehension of experimental methods than in previous decades. Some of the more challenging questions were "How can you study the genotype of an individual if it expresses a dominant trait," "Changes in the genotype and its relevance for the evolution of organisms," and "Twins and their role in genetic research."

\subsection{Quantitative trends in knowledge content}

The kappa statistic of classifying the questions into categories of knowledge content was 0.89 , which can be regarded as a strong agreement on the profile of the questions. The cross-tabulation of interrater classifications reveal that there was some disagreement between Molecules to organisms and the other categories (Supplementary Material, Figure 1).

As seen from the stacked area graph (Figure 6, Table 17), most questions in the 1920 s were in the category Molecules to organisms and the second most in Ecology. In the 1930s, questions on Genetics increased at the expense of Ecology, and in the 1940 s only a few questions on Ecology were asked. In the 1950s and 1960s, the profile stabilized and the percentage of questions in Molecules to organisms decreased. In 1944, 1945 and 1946 extraordinary exams were held, which slightly shifts the results in these years, and likely explains the lesser variation in categories during this period.

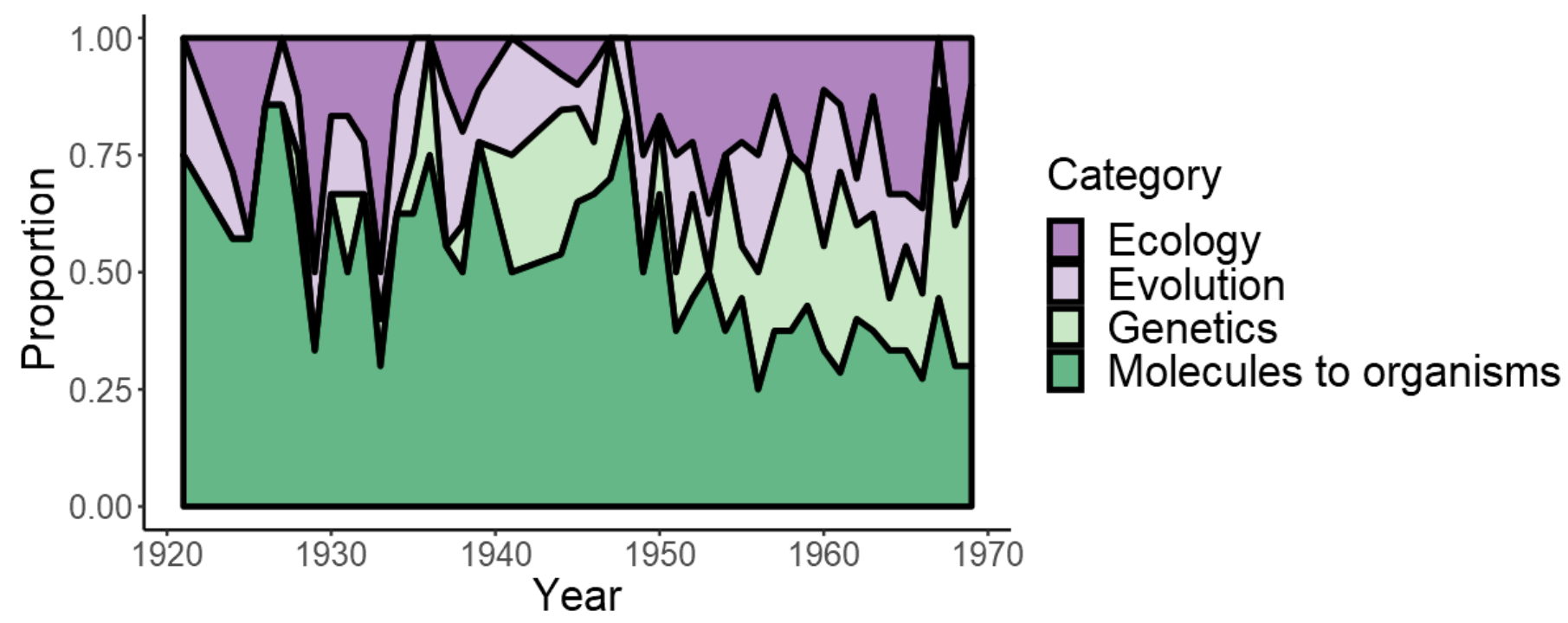

Figure 6. The yearly proportion of questions in different biological categories according to National Research Council (2012), namely Ecology, Evolution, Genetics, and From molecules to organisms. Only the years 1922, 1923, 1940, 1942 and 1943 are missing. 
When inspecting frequencies of biological categories across decades, there was no significant change in the proportions between the 1920 s and 1930 s or between the 1930 s and 1940s (Table 17), but as a whole, there was a significant change when moving from the 1920 s to $1940 \mathrm{~s}\left(\mathrm{X}^{2}=11.47, \mathrm{p}=0.01^{* *}\right.$, Fisher $\left.\mathrm{p}=0.01^{* *}\right)$. Between the 1920 s and 1940s, the increase in genetics and decrease in ecology explained this trend (Table 17). When moving from the 1940s to 1950s, there was a significant change in category proportions, while the 1950 s and 1960 s were similar in their knowledge content (Table 17). A decrease in Molecules to organisms and an increase in Genetics and Ecology stood for this result (Table 17).

Table 17. The percentages of different biological categories per decade. The last column shows the chisquare statistic, the $p$-value of the chi-square test and the p-value of Fisher's exact test. Fisher's exact test was used to compare frequencies between two successive decades, i.e. the interdecadal (ID) change. M \& O stands for Molecules to organisms.

\begin{tabular}{lllllll}
\hline & $\mathbf{n}$ & Ecology & Evolution & Genetics & M \& O & ID X $\mathbf{X}^{\mathbf{2}}$ \& ID Fisher \\
\hline $1920 \mathrm{~s}$ & 46 & $22 \%$ & $9 \%$ & $2 \%$ & $67 \%$ & \\
$1930 \mathrm{~s}$ & 83 & $17 \%$ & $17 \%$ & $7 \%$ & $59 \%$ & $3.5(0.32) \& 0.36$ \\
$1940 \mathrm{~s}$ & 83 & $7 \%$ & $12 \%$ & $18 \%$ & $63 \%$ & $5.1(0.05) \& 0.05$ \\
$1950 \mathrm{~s}$ & 78 & $23 \%$ & $13 \%$ & $22 \%$ & $42 \%$ & $11.04(0.01)^{* *} \&$ \\
& & & & & & $0.01 * *$ \\
$1960 \mathrm{~s}$ & 91 & $21 \%$ & $18 \%$ & $27 \%$ & $34 \%$ & $2.0(0.57) \& 0.58$ \\
\hline
\end{tabular}

\subsection{Biological novelties}

In total, 23 novel biological novelties were found in the exam questions, and the year of the academic establishment was delineated for the novelties (Table 18).

Table 18. Novel biological discoveries in the FME from 1921 to 1969.

\begin{tabular}{llll}
\hline Novelty & Type & Year of academic establishment & In FME \\
\hline Mendelism & Theory & 1910 (Gayon, 2016) & 1928 \\
Symbiosis & Concept & 1880 (Sapp, 1994) & 1930 \\
Water transport in plants & Concept & 1900 (Pittermann, 2010) & 1931 \\
Physiology of hearing & Concept & 1930 (Olson et al., 2012) & 1932 \\
Eusociality in bees & Discovery & 1925 (Couvillon, 2012) & 1932 \\
Yeast and fermentation & Discovery & 1880 (Barnett, 2000) & 1933 \\
Plankton and ecology & Discovery & 1910 (Barber \& Hilting, 2002) & 1933 \\
The cell nucleus and genetics & Theory & 1920 (Gayon, 2016) & 1936 \\
Genotype and phenotype & Concept & 1910 (Gayon, 2016) & 1936 \\
Enzymes & Discovery & 1930 (Poulsen \& Buchholz, 2003a, & 1937 \\
& & 2003 b) & 1937 \\
Hormones & Discovery & 1930 (Tata, 2005) & 1937 \\
Vitamins & Discovery & 1930 (Souganidis, 2012) & 1937 \\
Sex determination & Concept & 1920 (Stévant et al., 2018)
\end{tabular}




$\begin{array}{llll}\text { Mutation } & \text { Discovery } & 1930 \text { (Gayon, 2016) } & 1938 \\ \text { Modern synthesis and selection } & \text { Theory } & 1940 \text { (Gayon, 2016) } & 1945 \\ \text { Phototropism } & \text { Discovery } & 1930 \text { (Holland et al., 2009) } & 1951 \\ \text { Origin of life } & \text { Theory } & 1950 \text { (Fry, 2006) } & 1953 \\ \text { Neuron physiology } & \text { Concept } & 1952 \text { (Hodgkin \& Huxley, 1952) } & 1955 \\ \text { Mechanisms of speciation } & \text { Theory } & 1950 \text { (Smocovitis, 1992) } & 1957 \\ \text { Ecosystem } & \text { Theory } & 1950 \text { (Odum \& Barrett, 1971) } & 1959 \\ \text { Gene maps } & \text { Concept } & 1940 \text { (Koszul et al., 2012) } & 1959 \\ \text { DNA } & \text { Discovery } & 1955 \text { (Gayon, 2016) } & 1961 \\ \text { Transplantation and tissue } & \text { Discovery } & 1955 \text { (Barker \& Markmann, 2013) } & 1966 \\ \text { culture } & & & \end{array}$
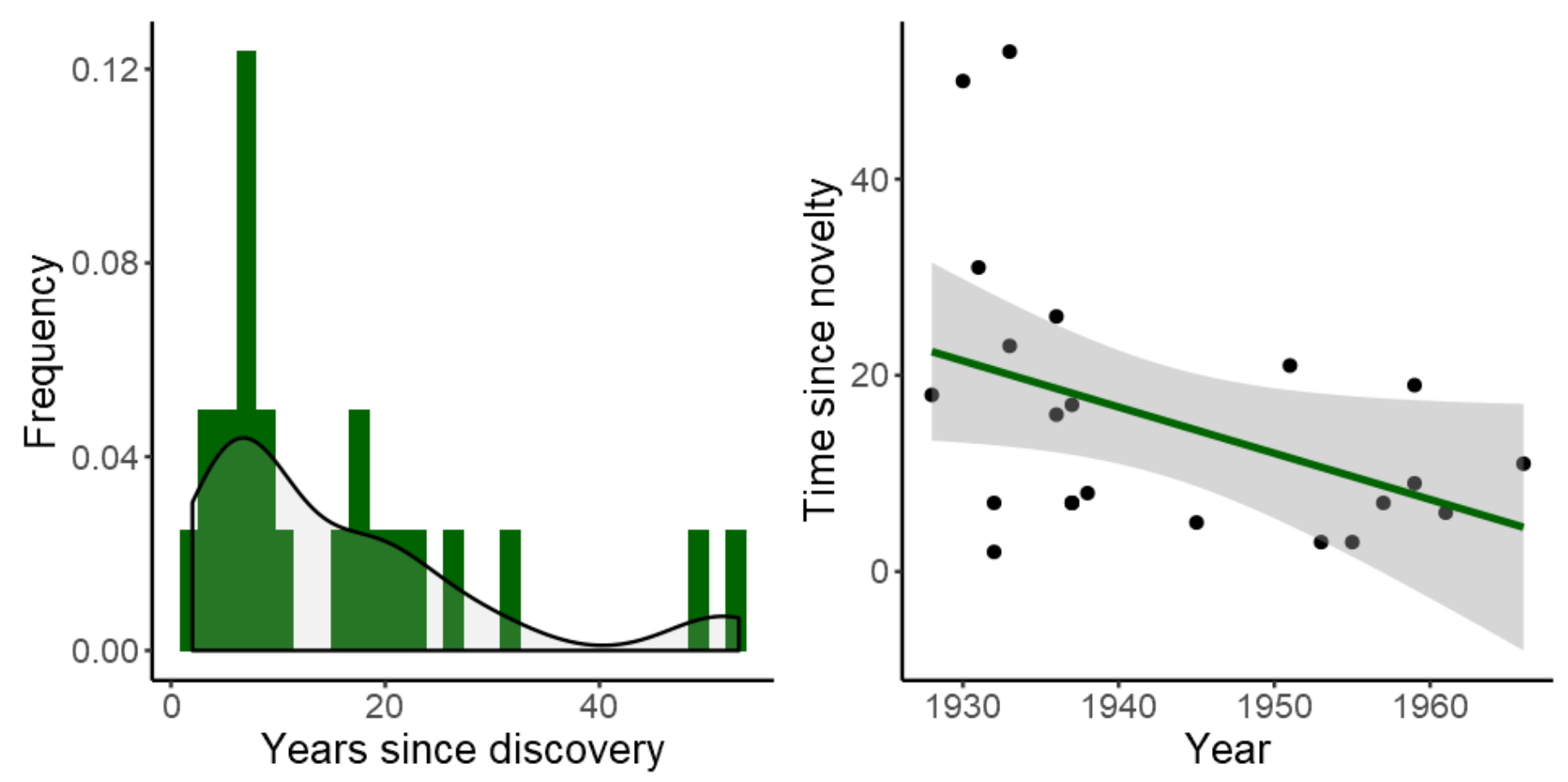

Figure 7. (Right) Histogram and density plot of the time of introduction, i.e. years since the novelty. (Left) Linear regression of the time of introduction as a function of the year when introduced.

The mean time of introduction to the exam was 15-5 years, while the median was 9. The bimodal nature of the density plot of the time of introduction is explained by the fact that approximations were usually made to the closest start of the decade (Figure 7). Otherwise, the density plot and the Poisson test clearly indicate that the rate of introduction is Poisson distributed $\left(\mathrm{p}<0.0001^{* * *}\right)$ with the event rate 15 .

A linear model could be fit to the yearly-dependence of the time of introduction (T) (Figure 7, Adj. R² $=0.73$, F-statistic $=62, \mathrm{p}<0.001^{* * *}$ ). Moreover, the slope was negative (estimate $-0.55,95 \%$ confidence interval $(-0.70,-0.41), \mathrm{p}<0.001^{* * *}$ ), indicating that the time of introduction decreased over the time period. 


\subsection{Quantitative trends in educational form}

The kappa statistic of classifying the questions according to Bloom's taxonomy was 0.83 , which can be regarded as a strong agreement on the educational form of the questions. Nonetheless, the cross-tabulation of interrater classifications reveal that there was some disagreement between knowing and comprehending as well as comprehending and applying (Supplementary Material, Figure 2).

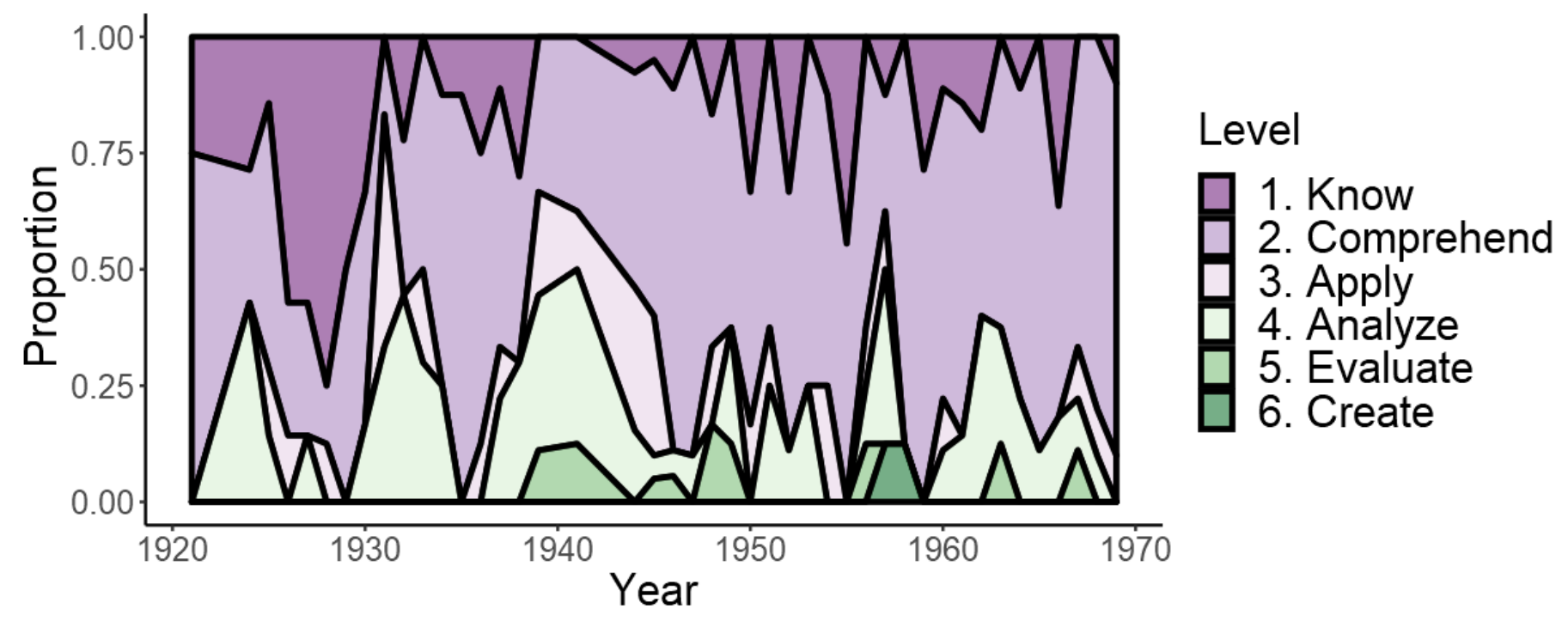

Figure 8. The yearly proportion of questions in different cognitive levels according to Krathwohl and Anderson (2009), namely Know, Comprehend, Apply, Analyze, Evaluate and Create. Only the years 1922, 1923, 1940, 1942 and 1943 are missing.

When counting frequencies for Bloom's taxonomy, most questions represented the Concept class, and therefore only the cognitive dimension was chosen for further analysis. As seen from the stacked area graph (Figure 8), the proportion of knowledgetesting questions was high in the 1920s but decreased already in the 1930s. In contrast, the number of comprehensive and analytic questions increased over time, and in the 1940s, the educational profile had settled (Figure 8). Interestingly, there was a peak in the cognitive demand of the questions between 1936 and 1944, when as much as $44 \%$ of the questions were ranked to be at level 3 or higher.

As seen from the frequency data, there was a significant change in the educational form between the 1920s and 1930s, and between the 1930s and 1940s, but not after the 1940s anymore (Table 19). The differences are attributable to the change in the number of questions requiring comprehension, application and analysis. 
Table 19. The cognitive demand (by Bloom's taxonomy) of assignments in each decade.

\begin{tabular}{lllllllll}
\hline & $\mathbf{n}$ & Know & Comprehend & Apply & Analyze & Evaluate & Create & ID Fisher \\
\hline $1920 \mathrm{~s}$ & 44 & $46 \%$ & $37 \%$ & $7 \%$ & $10 \%$ & $0 \%$ & $0 \%$ & \\
$1930 \mathrm{~s}$ & 83 & $15 \%$ & $49 \%$ & $11 \%$ & $24 \%$ & $1 \%$ & $0 \%$ & $<0.002^{* *}$ \\
$1940 \mathrm{~s}$ & 83 & $6 \%$ & $61 \%$ & $15 \%$ & $12 \%$ & $6 \%$ & $0 \%$ & $0.03^{*}$ \\
$1950 \mathrm{~s}$ & 79 & $16 \%$ & $61 \%$ & $8 \%$ & $11 \%$ & $1 \%$ & $3 \%$ & 0.07 \\
$1960 \mathrm{~s}$ & 92 & $11 \%$ & $66 \%$ & $4 \%$ & $16 \%$ & $2 \%$ & $0 \%$ & 0.43 \\
\hline
\end{tabular}

Interestingly, the percentage of assignments of different cognitive levels varied between biological categories (Figure 9, Table 20). Evolution had more analytic and evaluative questions than the other categories, while Ecology and Genetics had most applicative tasks. In Molecules to organisms, there were a few analytic and applicative tasks, but most were testing comprehension.

Table 20. The percentage of the cognitive demand (by Bloom's taxonomy) in each biological category.

\begin{tabular}{llllllll}
\hline & $\mathbf{n}$ & Know & Comprehend & Apply & Analyze & Evaluate & Create \\
\hline Ecology & 69 & $19 \%$ & $55 \%$ & $12 \%$ & $14 \%$ & $0 \%$ & $0 \%$ \\
Evolution & 54 & $15 \%$ & $37 \%$ & $2 \%$ & $35 \%$ & $11 \%$ & $0 \%$ \\
Genetics & 64 & $9 \%$ & $52 \%$ & $19 \%$ & $14 \%$ & $3 \%$ & $3 \%$ \\
Molecules to organisms & 196 & $17 \%$ & $65 \%$ & $7 \%$ & $10 \%$ & $1 \%$ & $0 \%$ \\
\hline
\end{tabular}

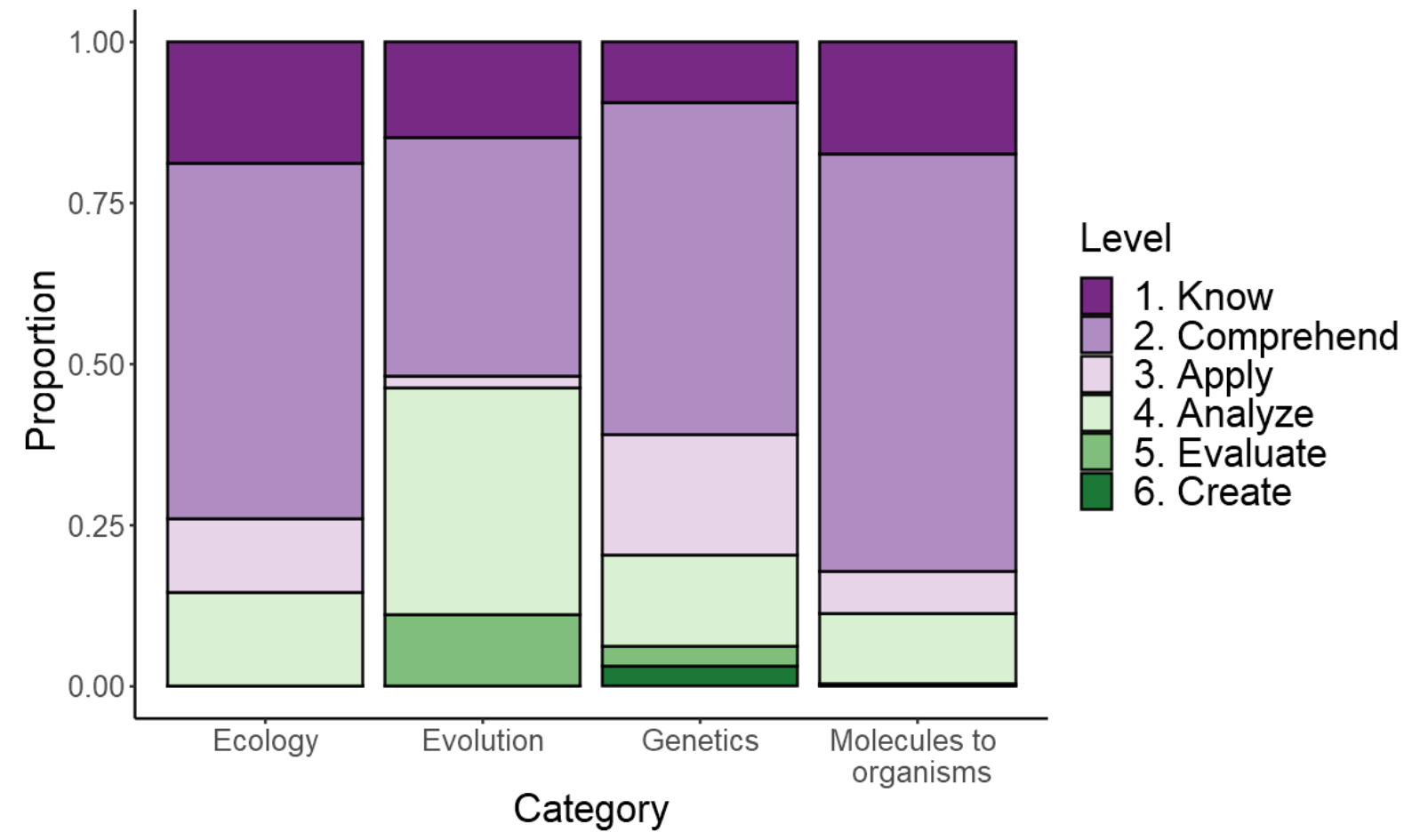

Figure 9. The percentage of the cognitive demand (by Bloom's taxonomy) in each biological category. 
Lastly, pairwise comparisons of the frequencies of the four categories show that Evolution stands out from the other categories, and Genetics differs from Molecules to organisms, whereas the difference between Genetics and Ecology as well as Ecology and Molecules to organisms is non-significant (Table 21).

Table 21. The results of the chi-squared test of independence and pairwise comparisons.

\begin{tabular}{llll}
\hline & Ecology & Evolution & Genetics \\
\hline Evolution & $<0.001^{* * *}$ & - & - \\
Genetics & 0.19 & $<0.001^{* * *}$ & - \\
Molecules to organisms & 0.46 & $<0.001^{* * *}$ & $0.001^{* *}$ \\
\hline
\end{tabular}

\section{Discussion}

\subsection{Trends in knowledge content - the FME reflects Finnish academia}

The MEB has always consisted of censors from Finnish academia (mostly from the University of Helsinki but later also from other universities), and hence it was assumed that the FME reflects both contemporary national and international academic trends (Kaarninen \& Kaarninen, 2002). However, this connection has never been systematically demonstrated for biology. Here, we show that FME mirrors the Finnish history of biology both in Finnish academia and the upper secondary school system. The changes in question content further reflect the major advancements in biology as a field, and a great number of questions concerned novel topics discovered during the study period (Table 18). In addition, also political, social, and economic trends in Finnish history can be seen in the question content.

In the 1920s, the focus on comparative zoology in the FME nicely reflects the emphasis on this subject in Finnish zoology. In the beginning of the $20^{\text {th }}$ century, Finnish zoology was greatly influenced by scholars in Germany, where evolutionary morphology had a strong foothold in the beginning of the century (Levit et al., 2014). However, it is not clear why so few systematic questions were asked in zoology, as zootaxonomy was firmly established in Finnish academia in the $19^{\text {th }}$ century and well presented in contemporary school books (Kivirikko, 1923; Leikola, 2011). As the MEB does not produce protocols or other documents of the exam preparation, the work of the MEB must be interpreted from secondary sources (Kaarninen \& Kaarninen, 2002). It seems that there was an agreement in the MEB that the botanical questions focused on systematical aspects, as botanical research in Finnish academia heavily concentrated on taxonomic research rather than plant physiology in the beginning of 
the $2^{\text {th }}$ century (Morton et al., 1999). This is also reflected by the fact that the professorship of plant physiology at the University of Helsinki was instated no sooner than 1939, while several positions were already devoted to plant systematics (Autio, 2000). In contrast, the professorship of zoophysiology had been instated already in 1910 alongside positions in systematics and ecology (Autio, 2000). In the 1930s, the interest for plant physiology rose in Finnish academia thanks to the works of Fredrik Elfving, which apparently led to more assignments on plant physiology in the FME and likely left room for taxonomic questions in zoology (Autio, 2000; Morton et al., 1999). However, further investigation into the history of both university and secondary school teaching is required to assess whether this focus on plant systematics and comparative zoology was a general trend in Finnish universities and schools or only a peculiarity of the FME.

In the 1930 s and 1940s, the increased focus on genetics and the evidence and foundations of the evolutionary theory reflected the ongoing academic debate and establishment of the Modern Synthesis both internationally and in Finland (Gayon, 2016). Interestingly, the only purely racist and eugenic questions were asked in 1929 and 1930, which we see to mirror both the academic and political history of Finland. As for academia, Mattila (1999) reports that eugenic thoughts were introduced and advocated in the 1910 s mainly by three leading Swedish-speaking professors: Ossian Schauman, professor of internal medicine, Jarl Hagelstam lecturer in neurology, and Harry Federley, the first professor of genetics, all based at the University of Helsinki. He notes that their eugenic ideas were faced with suspicion by several contemporary physicians at first, although he remarks that the reason was mostly due to unfamiliarity with the new field of genetics.

Towards the 1920s, eugenics became more widely acknowledged in Finnish academia, and the Finnish eugenicists collaborated with colleagues at the State Institute for Racial Biology in Sweden and the Kaiser Wilhelm Institute of Anthropology, Human Heredity, and Eugenics in Germany (Hietala, 2009; Mattila, 1999). Schauman, Hagelstam and Federlay were all involved in leading the committee on sterilization legislation that prepared the Finnish sterilization law passed in 1934 (Hietala, 2009; Mattila, 1999). Furthermore, eugenics was presented as a part of human heredity in Finnish schoolbooks of biology from the 1920s well into the 1940s, as was the case in both Sweden and Germany (Mattila, 1999; Wendt, 2015).

Taken together, eugenic thoughts were not uncommon in Finnish academia or school material from the 1920 s to the 1940s, and therefore the lack of eugenics in the 
FME after 1930 is interesting. In the 1930s, Väinö Lassila, professor of anatomy, and Erkki Vala, chief editor of the periodical Tulenkantajat, criticized the sterilization law and warned how similar legislation was abused by the Nazi Party in Germany (Mattila, 1999). The right extremist Lapua Movement was quenched in 1932, and therefore we speculate that the Finnish political climate might have influenced the MEB's willingness to ask eugenic questions later in the 1930s. Nonetheless, how eugenics was manifested in Finnish secondary school teaching in the 1930 s amidst both academic and political trends would need further clarification.

Interestingly, several of the physiological questions in the 1940s examined nutrition in both plants and humans, which may have to do with academic as well as political and economic factors. As for academic factors, the Finnish Nobelist A.I. Virtanen performed foundational research on nitrogen metabolism and biochemistry in the 1930 s and initiated several projects on public nutrition and health together with his colleagues (Heikonen, 1990; Perko, 2014). However, this trend was not unique to Finland as public nutrition and health programs were started and also planned in other Western countries (Mayhew, 1988). As for political and economic factors, one may also speculate whether the scarcity of the wartime affected this trend.

Moreover, the wartime may have contributed to the decline in ecological questions, while biological questions with medical relevance such as genetics and physiology were emphasized. The interrelationship between physical sciences and wartime is widely recognized: science affects weapons and warfare, and warfare steers science in an applied direction to produce better weapons, the typical example being the Manhattan project (Roland, 1985). As for medicine, the relationship is more controversial, with some authors supporting the view that war may also direct and advance medical research (Cooter, 1990). Nonetheless, we find an interesting theme for further research to see whether warfare would affect biological research and teaching by emphasizing themes important for warfare, such as public nutrition and medical aspects.

The new focus on developmental biology may reflect the rise of experimental embryology epitomized by Spemann's induction experiments and followed by several embryologists in Finland (Leikola, 2003). Gunnar Ekman and Sulo Toivonen were both prominent experimental embryologists who were involved in writing school books in biology for upper secondary schools and actively popularized their field of study (Leikola, 2003). Again, further research on secondary school teaching would reveal to what extent developmental biology was also emphasized outside the FME. 
In the 1950s, the establishment of the exam's biological content may reflect the higher availability of secondary education to different societal segments, leading to an increase in teachers and academics and less random selection of questions (Kaarninen \& Kaarninen, 2002). This would correspond to the progress in the US, where the increasing number of students and a reaction against highly specialized courses in zoology and botany were the leading factors for establishing the modern curriculum in biology in the 1950s and 1960s (Rosenthal, 1990). Moreover, advancements in various fields of ecology of the time likely initiated the renaissance of ecology in the exam in the same way as in the US (McComas, 2002; Odum \& Barrett, 1971). One can also speculate whether the increased number of examinees and teachers also forced the MEB to ask more questions in ecology and traditional natural history, as these were considered to be more familiar to both teachers and students (Kaarninen \& Kaarninen, 2002). For example, Suomalainen and Segerstråle (1953) had redesigned their school book to start with ecology for this reason, suggesting that these ideas were common within the secondary school of the 1950 .

Interestingly, there was no significant change in the biological content of the exam in the 1960 s in contrast to mathematics and the physical sciences (Kaarninen \& Kaarninen, 2002). This may be attributable to the fact that the pressure of the technological advancement of the Soviet Union in the beginning of the decade was seen mainly in physical sciences, while no comparable pressure was evident for biology (Graham, 1993). Furthermore, the exam had already been reformed a lot in the previous decade, which was likely deemed to be sufficient.

During the study period, we see a drastic change of assessment content from classical natural history to a more varied selection of topics in evolution, genetics and ecology. This is most evident in botany, as questions relating to plant sciences and especially plant systematics diminished from a major component of the questions in the 1920 s to marginal component in the 1950 os and 1960s. This is mirrored in school curricula and activities, such as the gathering of student herbaria. Whereas in the 1920 s each student was to collect around 200 species of plants to their personal herbarium, the number of species was lowered multiple times, and eventually in 1969, the collection of personal student herbaria was dropped from the Finnish school system (Saarinen et al., 2016; Virtanen \& Kankaanrinta, 1989). A similar trend was seen in classical non-human zoology, which gets increasingly replaced by human physiology during our study period. This trend is still evident in modern biology curricula and FME. Some authors have raised concern on the poor species 
identification skills of contemporary students, which can in part result from this shift away from systematic botany and zoology (Immonen et al., 2006).

The time of introduction of biological novelties decreased during the study period. This illustrates the relationship between the FME and Finnish academia, and the fact that exam developers were not afraid of introducing novelties in exams soon after their academic establishment. The pattern is evident even considering that the estimation of the year of academic establishment of biological novelties is difficult and at times arguably subjective (Supplementary Material). The decrease in the lag of time between academic establishment and inclusion in the FME can in part be explained by improved technology in information distribution and eventual electronic information distribution.

\subsection{Trends in educational form - high standard from the beginning}

This study contradicts the statement by Kaarninen and Kaarninen (2002) and Virta (2014) that the test battery in humanities and sciences would have tested only knowledge of factual details. Apparently, this may apply to other subjects, but not biology. In contrast, the exam in the 1930s was already rich in comprehensive and analytic components, and the educational standard was established in the 1940s, after which no significant improvements were made. Rostila (2014) and Lindholm (2017) report that about 20\% of the questions in the modern FME in biology (2009-2015) were on level 3 or higher in Bloom's taxonomy, indicating that the exam from the 1930 s to 1960 s was mostly as cognitively demanding as the modern exam. The problem with analyzing historical exam questions is that although the question itself is cognitively demanding, it remains unclear how much cognitive input was required for a given grade in the end. Nonetheless, the inclusion of several applicative, analytic and evaluative questions in the FME proves that the MEB has been subconsciously aware of good forms of assessment before the conceptualization of Bloom's taxonomy.

The most cognitively demanding period of the exam was around 1940, which coincides with the ongoing academic debate on the Modern Synthesis. The most cognitively demanding questions were asked on evolution and genetics, which also reflects the potential influence of the Modern Synthesis on the exam. Furthermore, Lindholm (2017) did not find the cognitive demand of evolution and genetics higher than that of the other categories in contemporary exams, suggesting further that this pattern is specific to the given historical context. The science and concepts of ecology was still in its infancy before the 1950s, and before that ecology was more or less 
descriptive natural history, upon which it was hard to construct good analytic questions. The lack of applicative and analytic questions in the category Molecules to organisms may be explained by the lack of experimental instrumentation in schools, and probably because of the perceived technicality of the subject (Suomalainen \& Segerstråle, 1953).

\section{Conclusions}

In conclusion, here we summarize for the first time the Finnish matriculation examination from a historical perspective. The FME in biology from 1921 to 1969 followed well both international and national academic trends and transferred them to the exam within 10-20 years. The data shows that the inclusion of biological questions to the exam follows a similar pattern: initial caution, excitement, and stabilization. Contrary to popular stereotypes, the old FME in biology had a high standard of assessment already from the 1930s onwards, comparable to the level of the modern exam. This shows that educators have been aware of good forms of assessment before its theoretical conceptualization. In addition, the cognitively most demanding questions were on evolution, proving that academic excitement in a given discipline may give rise to tasks of a high educational standard. The old FME questions may be used as an inspiration for devising good essay questions even for future generations of students.

\section{References}

Ahvenisto, I., Van den Berg, M., Löfström, J., \& Virta, A. (2013). Kuka oikeastaan asettaa opetuksen tavoitteet? Yhteiskuntaopin taidolliset tavoitteet ja niiden arviointi opetussuunnitelmien perusteissa ja ylioppilastutkinnossa. Kasvatus \& Aika, 7(3), 40-55.

Autio, V.-M. (2000). Helsingin yliopiston opettaja- ja virkamiesluettelo 1918-2000. University of Helsinki.

Barber, R. T., \& Hilting, A. K. (2002). History of the study of plankton productivity. In P. J. Willaims, D. N. Thimas, \& C. S. Reynolds (Eds.), Phytoplankton Productivity: Carbon assimilation in marine and freshwater ecosystems (pp. 16-43): Blackwell Science Ltd. doi: https://doi.org/10.1002/9780470995204.ch2

Barker, C. F., \& Markmann, J. F. (2013). Historical overview of transplantation. Cold Spring Harbor perspectives in medicine, 3(4), a014977. doi:https://doi.org/10.1101/cshperspect.a014977.

Barnett, J. A. (2000). A history of research on yeasts 2: Louis Pasteur and his contemporaries, 1850-1880. Yeast, 16(8), 755-771. doi:https://doi.org/10.1002/1097-0061(20000615)16:8

Bloom, B. S. (1956). Taxonomy of educational objectives. Vol. 1: Cognitive domain. New York: McKay, 20-24. 
Caroli, D. (2019). 'And all our classes turned into a flower garden again'-science education in Soviet schools in the 1920s and 1930s: the case of biology from Darwinism to Lysenkoism. History of education, 48(1), 77-98. doi:https://doi.org/10.1080/0046760X.2018.1529252 Cohen, L., Manion, L., \& Morrison, K. (2013). Research methods in education: Routledge.

Cooter, R. (1990). Medicine and the Goodness of War. Canadian Bulletin of medical history, 7(2), 147-159.

Couvillon, M. (2012). The dance legacy of Karl von Frisch. Insectes sociaux, 59(3), 297-306. doi:http://dx.doi.org/10.1007/s00040-012-0224-Z

Eymard-Simonian, C. (2000). La problématisation méthodologique dans la formation à la recherche en éducation. Cahiers de la recherche en éducation, 7(2), 293-312. doi:https://doi.org/10.7202/1016939ar

Faire, L. (2016). Research methods for history: Edinburgh University Press.

Fry, I. (2006). The origins of research into the origins of life. Endeavour, 3O(1), 24-28. doi:https://doi.org/10.1016/j.endeavour.2005.12.002

Gall, M. D., Borg, W. R., \& Gall, J. P. (1996). Educational research: An introduction: Longman Publishing.

Gayon, J. (2016). From Mendel to epigenetics: History of genetics. Comptes rendus biologies, 339(7-8), 225-230. doi:https://doi.org/10.1016/j.crvi.2016.05.009

Goldenfeld, N., \& Woese, C. (2007). Biology's next revolution. Nature, 445(7126), 369. doi:https://doi.org/10.1038/445369a

Graham, L. R. (1993). Science in Russia and the Soviet Union: A short history: Cambridge University Press.

Hallgren, K. A. (2012). Computing inter-rater reliability for observational data: an overview and tutorial. Tutorials in quantitative methods for psychology, 8(1), 23.

Happonen, P., Holopainen, M., Sotkas, P., Tihtarinen-Ulmanen, M., \& Venäläinen, J. (2016). Bios 5: Biologian sovellukset (LOPS 2016): Sanoma Pro.

Heikonen, M. (1990). AIV: keksintöjen aika: Kirjayhtymä.

Hietala, M. (2009). Eugeniikan ja rotuhygienian tausta ja seuraukset. Tieteessä tapahtuu, 27(8), 14-19.

Hodgkin, A. L., \& Huxley, A. F. (1952). A quantitative description of membrane current and its application to conduction and excitation in nerve. The Journal of physiology, 117(4), 500544 .

Holland, J. J., Roberts, D., \& Liscum, E. (2009). Understanding phototropism: from Darwin to today. Journal of experimental botany, 6o(7), 1969-1978. doi:https://doi.org/10.1093/jxb/erp113

Immonen, S., Mehtälä, E., Paasivaara, S., \& Suontausta, T. (2006). Valtakunnallinen lähtötasokoe kertoi 7-luokkalaisten biologian osaamisesta. Natura, 4, 7-12.

Jenkins, E. W. (1979). The development of school biology 1918-1945. History of education, 8(1), 59-73.

Kaarninen, M., \& Kaarninen, P. (2002). Sivistyksen portti: Ylioppilastutkinnon historia: Otava.

Kinchin, I. M. (2010). Solving Cordelia's dilemma: Threshold concepts within a punctuated model of learning. Journal of Biological Education, 44(2), 53-57.

Kivirikko, K. E. (1923). Biologia oppikoulujamme ylempiä luokkiq sekä itseopiskelua varten (2nd ed.): Werner Söderström Osakeyhtiö.

Koszul, R., Meselson, M., Van Doninck, K., Vandenhaute, J., \& Zickler, D. (2012). The centenary of Janssens's chiasmatype theory. Genetics, 191(2), 309-317.

doi:https://doi.org/10.1534/genetics.112.139733

Krathwohl, D. R., \& Anderson, L. W. (2009). A taxonomy for learning, teaching, and assessing: A revision of Bloom's taxonomy of educational objectives: Longman.

Kurzweil, R. (2014). The singularity is near. In Ethics and emerging technologies (pp. 393-406): Springer. 
Leikola, A. (2003). The Finnish tradition of developmental biology. International Journal of Developmental Biology, 33(1), 15-20.

Leikola, A. (2011). History of Zoology in Finland, 1828-1918: Societas Scientiarum Fennica.

Levit, G. S., Hossfeld, U., \& Olsson, L. (2014). The Darwinian revolution in Germany: from evolutionary morphology to the modern synthesis. Endeavour, 38(3-4), 268-278. doi:https://doi.org/10.1016/j.endeavour.2014.10.010

Lindholm, S. (2017). Biologian ylioppilaskokeiden haasteet: Koetehtävien sisällöt ja vaikeustasot sekä nüden vaikutus todelliseen osaamiseen. University of Helsinki, Helsinki.

Marklund, G., \& Jalas, A. (1933). Biologia oppikoulujen lukioluokkia varten (1st ed.): Werner Söderström Osakeyhtiö.

Marklund, G., \& Jalas, A. (1943). Biologia oppikoulujen lukioluokkia varten (5th ed.): Werner Söderström Osakeyhtiö.

Mattila, M. (1999). Kansamme parhaaksi: Suomen historiallinen seura Helsinki.

Mayhew, M. (1988). The 1930s nutrition controversy. Journal of Contemporary History, 23(3), 445-464.

Mayr, E. (1982). The growth of biological thought: Diversity, evolution, and inheritance: Harvard University Press.

Mayr, E. (1997). This is biology: The science of the living world: Universities Press.

McComas, W. F. (2002). The ideal environmental science curriculum: I. history, rationales, misconceptions \& standards. The American Biology Teacher, 64(9), 665-673.

McHugh, M. L. (2012). Interrater reliability: the kappa statistic. Biochemia medica, 22(3), 276282. doi:https://doi.org/10.11613/bm.2012.031

McTighe, J., \& Ferrara, S. (1998). Assessing Learning in the Classroom. Student Assessment Series: ERIC.

Morton, A., Kukkonen, I., \& Enroth, J. (1999). Kasvitieteen historia: Kuvaus kasvitieteen vaiheista muinaisajoista nykypäivään: Gaudeamus.

National Research Council. (2009). A new biology for the 21st century: National Academies Press.

National Research Council. (2012). A framework for K-12 science education: Practices, crosscutting concepts, and core ideas: National Academies Press.

Neuendorf, K. A. (2016). The content analysis guidebook: Sage.

Odum, E. P., \& Barrett, G. W. (1971). Fundamentals of ecology (Vol. 3): Saunders Philadelphia.

Olson, E. S., Duifhuis, H., \& Steele, C. R. (2012). Von Békésy and cochlear mechanics. Hearing research, 293(1-2), 31-43. doi:https://doi.org/10.1016/j.heares.2012.04.017

Perko, T. (2014). Mies, liekki ja unelma: Nobelisti AI Virtasen elämäntyö: Otava.

Pittermann, J. (2010). The evolution of water transport in plants: an integrated approach. Geobiology, 8(2), 112-139. doi:https://doi.org/10.1111/j.1472-4669.2010.00232.x

Poulsen, P. B., \& Buchholz, H. K. (2003a). History of enzymology with emphasis on food production. In J. R. Whitaker, A. G. J. Voragen, \& D. W. S. Wong (Eds.), Handbook of food enzymology (pp. 11-20): CRC Press.

Poulsen, P. B., \& Buchholz, H. K. (2003b). History of enzymology with emphasis on food production. Handbook of food enzymology, 11-20.

R Core Team. (2019). R: A language and environment for statistical computing. In. Vienna, Austria: R Foundation for Statistical Computing.

Roland, A. (1985). Science and war. Osiris, 1, 247-272.

Rosenthal, D. B. (1990). What's past is prologue: Lessons from the history of biology Education. The American Biology Teacher, 52(3), 151-155. doi:https://doi.org/10.2307/4449067

Ross, S. M. (2017). Introductory statistics: Academic Press.

Rostila, A. (2014). Biologian ainereaalin tehtävätyypit, teemat ja tiedolliset haasteet vuosina 2006-2009. University of Helsinki, Helsinki.

Saarinen, K., Jantunen, J., \& Pulli, A. (2016). Vanhojen koululaisherbaarioiden kertomaa - The flora of Eastern Finland as reflected in old school herbaria between 1925 and 1969. Lutukka, 32(2), 52-61. 
Sáez-Rosenkranz, I. (2016). Historical method applied to educational research. Revista d'Innovació i Recerca en Educació, 9(2), 106. doi:https://doi.org/10.1344/reire2016.9.2928

Sapp, J. (1994). Evolution by association: a history of symbiosis: Oxford University Press.

Smocovitis, V. B. (1992). Unifying biology: The evolutionary synthesis and evolutionary biology. Journal of the History of Biology, 25(1), 1-65.

Sorsa, V., Leikola, A., Mattila, R., \& Sorsa, M. (1966). Lukion biologia (1st ed.): Werner Söderström Osakeyhtiö.

Souganidis, E. (2012). Nobel laureates in the history of the vitamins. Annals of Nutrition and Metabolism, 61(3), 265-269. doi:https://doi.org/10.1159/000343122

Stévant, I., Papaioannou, M. D., \& Nef, S. (2018). A brief history of sex determination. Molecular and cellular endocrinology, 468, 3-10. doi:https://doir.org/10.1016/j.mce.2018.04.004

Suomalainen, P., \& Segerstråle, S. (1953). Yleisbiologia oppikouluja varten (2nd ed.): Kustannysosakeyhtiö Otava.

Tata, J. R. (2005). One hundred years of hormones. EMBO reports, 6(6), 490-496. doi:https://doi.org/10.1038/sj.embor.7400444

Tikkanen, G. (2010). Kemian ylioppilaskokeen tehtävät summatïvisen arvioinnin välineenä. University of Helsinki, Helsinki.

Tuulosniemi, S. (2019). Elämää kynän ja paperin jälkeen: Ylioppilaskokelaan tekniset valmiudet tuottaa kuvia biologian ensimmäisessä digitaalisessa ylioppilaskokeessa keväällä 2018. Lahti University of Applied Sciences, Lahti.

Vaskuri, J. (2017). Oppiennätyksistä opetussuunnitelman perusteisïn: lukion kemian kansallisen opetussuunnitelman kehittyminen Suomessa vuosina 1918-2016. University of Jyväskylä, Jyväskylä.

Wendt, S. (2015). Rasbiologisk upplysning: En analys av svenska läroböcker 1930-195o. Umeå University, Umeå.

Vilhunen, A.-S., \& Hopia, A. (2012). Kehittämistutkimus: Tutkimuksellinen proteiinien opiskelu molekyyligastronomian kontekstissa. University of Helsinki, Helsinki.

Virta, A. (2014). Historia ja yhteiskuntaoppi reaalikokeessa 1921-1969 - koetehtävien kehitys oppiennätysten ja opetusta koskevan keskustelun näkökulmasta. Ennen ja Nyt : Historian Tietosanomat, 1(4).

Virtanen, L., \& Kankaanrinta, I. (1989). Biologia koulussa. Yliopistopaino.

Vitikainen, R. (2014). Muistitietoa vai menetelmien soveltamista? Kognitiiviset tiedot ja taidot maailmanuskontojen ylioppilaskoekysymyksissä vuosina 1996-2013. University of Helsinki, Helsinki.

Vuorio-Lehti, M. (2007). Valkolakin hohde-Keskustelua ylioppilastutkinnon merkityksestä Suomessa toisen maailmansodan jälkeen. Kasvatus \& Aika, 1(1), 19-33. 